\title{
Review Article \\ Characterization, Preparation, and Purification of Marine Bioactive Peptides
}

\author{
Xueqin Wang, Huahua Yu, Ronge Xing, and Pengcheng Li \\ Institute of Oceanology, Chinese Academy of Sciences, Qingdao 266071, China \\ Correspondence should be addressed to Pengcheng Li; pcli@qdio.ac.cn
}

Received 24 February 2017; Revised 25 May 2017; Accepted 1 June 2017; Published 6 July 2017

Academic Editor: Wuyuan Lu

Copyright (c) 2017 Xueqin Wang et al. This is an open access article distributed under the Creative Commons Attribution License, which permits unrestricted use, distribution, and reproduction in any medium, provided the original work is properly cited.

\begin{abstract}
Marine bioactive peptides, as a source of unique bioactive compounds, are the focus of current research. They exert various biological roles, some of the most crucial of which are antioxidant activity, antimicrobial activity, anticancer activity, antihypertensive activity, anti-inflammatory activity, and so forth, and specific characteristics of the bioactivities are described. This review also describes various manufacturing techniques for marine bioactive peptides using organic synthesis, microwave assisted extraction, chemical hydrolysis, and enzymes hydrolysis. Finally, purification of marine bioactive peptides is described, including gel or size exclusion chromatography, ion-exchange column chromatography, and reversed-phase high-performance liquid chromatography, which are aimed at finding a fast, simple, and effective method to obtain the target peptides.
\end{abstract}

\section{Introduction}

The oceans occupy more than $70 \%$ of the earth and are a rich natural resource for many bioactive compounds in organisms such as fish, shellfish, molluscs, univalves, cephalopods, crustaceans, and echinoderms, which significantly contribute to economic and research development $[1,2]$. Since marine organisms live in complex habitats and are exposed to extreme conditions, such as salinity, pressure, temperature, and illumination, they produce a wide variety of secondary metabolites that cannot be found elsewhere [2]. In addition, the marine organisms also have special structures and constitute nearly half of the worldwide biodiversity, like antioxidant activity, antimicrobial activity, anticancer activity, antihypertensive activity, anti-inflammatory activity, and so forth [3].

In general, bioactive peptides often have 3 to 20 amino acid residues, and their biological activities are based on their amino acid composition and sequence [4]. Recently, much attention has been paid to unravelling the structural, compositional, and sequential properties of bioactive peptides [3]. This review highlights the characteristics of marine peptides with biological activities as well as the preparation and purification of such peptides.

\section{Marine Peptides with Different Bioactivities}

Many marine organisms are exposed to more extreme conditions than that on land, which make the marine bioactive peptides have significant different amino acid compositions and sequences from land bioactive peptides; besides, the species and amounts of marine bioactive peptides are more than that of land bioactive peptides. Moreover, Marine bioactive peptides can be obtained from various marine animals, plants, and lower organisms. Each is unique as a species, considering its great taxonomic diversity and special characteristics, marine bioactive peptides have better bioactivity in some areas than land bioactive peptides.

2.1. Antioxidative Peptides. Oxidation is an essential reaction in all living organisms, as the formation of free radicals and other reactive oxygen species (ROS) plays an important role in signal transduction [5]. However, excess free radicals can cause many human diseases, such as heart disease, strokes, arteriosclerosis, diabetes, and cancer [6]. Antioxidants are compounds that can inhibit oxygen-dependent lipid oxidation, usually by scavenging and thereby neutralizing free radicals [7]. In addition, the synthetic antioxidants such 
as butylated hydroxyanisole (BHA) and butylated hydroxytoluene (BHT) have long-term safety problems and negative consumer perception [8]. For these reasons, the demand for natural antioxidants has increased recently.

Compared to the earth environment, marine organisms live in complex habitats and are exposed to extreme conditions; thus, some of them have higher antioxidant activities. In recent years, many antioxidative peptides from marine organisms have been found, such as those from Hoki (Johnius belengerii) frame [9], Mackerel (Pneumatophorus japonicus) [10], Mussel (Perna canaliculus) muscle [11], Croaker (Otolithes ruber) [12], Tuna backbone [13], and Prawn (Penaeus japonicus) [14], and these peptides show significant free radical scavenging activities (Table 1). Moreover, every year a considerable amount of total catch is discarded [15], causing environmental pollution and the wasting of resources. Therefore, many researchers used seafood byproducts to prepare antioxidative peptides, like Sardinelle (Sardinella aurita) by-products [16], Abalone (Haliotis discus hannai Ino) viscera [17], Nile Tilapia skin [18], Jumbo Squid (Dosidicus gigas) skin [19], and so forth, and, thus, these studies were increasing the utilization value of marine organisms.

The measurement of antioxidant activity is an important screening method. Some chemical methods are used, including reducing power, hydroxyl radical scavenging activity, superoxide anion radicals scavenging activity, scavenging reactive oxygen species, and inhibition of lipid peroxidation [20-23]. Despite the wide use of these chemical antioxidant activity assays, none of them take into account the bioavailability, uptake, and mechanism of the antioxidant compounds [24]. In recent years, cell culture models provide an approach that is cost-effective and relatively fast and can explain metabolic issues [25]. One approach is to use the cellular antioxidant status measured by the methyl thiazolyl tetrazolium assay and protect HepG2 cells against $\mathrm{H}_{2} \mathrm{O}_{2}$-induced cytotoxicity [26, 27]. However, since the concentration of $\mathrm{H}_{2} \mathrm{O}_{2}$ is not clear, this method should have a preliminary experiment. Another effective cellular antioxidant activity (CAA) assay is also related to HepG2 cells $[25,28]$, and the CAA assay is considered a superior indicator of in vivo activity compared with in vitro assays because it involves the exposure of the antioxidants to the complexity of biological substrates under physiological conditions [29]. Certainly, the best antioxidant assays are from animal models and human studies [30], but they are expensive, time-consuming, and not suitable for the initial screening [24]. In other words, although there is a great multiplicity of methods used for antioxidant testing, there are no approved standardized methods.

2.2. Angiotensin-I-Converting Enzyme (ACE) Inhibitory Peptides. Hypertension is one of the most common cardiovascular diseases worldwide [54]. Approximately $54 \%$ of strokes, $47 \%$ of ischaemic heart disease, $75 \%$ of hypertensive disease, and $25 \%$ of other cardiovascular diseases worldwide were attributable to high blood pressure [55]. Among the processes related to hypertension, Angiotensin-I-Converting Enzyme (ACE) plays an important role in the regulation of blood pressure. ACE can catalyse the conversion of angiotensin I to angiotensin II, and angiotensin II is a potent vasoconstrictor that increases peripheral vascular resistance and consequently elevates arterial pressure $[56,57]$. Therefore, in the development of drugs to control high blood pressure, ACE inhibitors and angiotensin receptor blockers are now used clinically for the treatment of various cardiovascular diseases [58]. However, the synthetic drugs such as captopril, lisinopril, and enalapril [59] are believed to have certain side effects such as a cough, skin rash, loss of taste, or angioneurotic oedema $[60,61]$. Due to these adverse side effects, there is a trend towards encouraging the development of natural ACE inhibitors.

In recent years, naturally occurring peptides with ACE inhibitory activity were obtained from various marine organisms such as Green Algae [62], Sea Cucumber (Acaudina molpadioides) [31], Tuna [32], Sole (Limanda aspera) [33], Blue Mussels (Mytilus edulis) [34], Jumbo Squid (Dosidicus gigas) [63], Oysters (Crassostrea gigas) [64], and Shrimp [35, 36]. In addition, fish are sources of numerous bioactive peptides with ACE inhibitory activities including Alaska Pollack (Theragra chalcogramma) frame [37] and skin [38], Flounder fish (Paralichthys olivaceus) [65], Tuna [32], Shark [39], and Cod (Gadus morhua) [66]. Marine organisms may become important protein resources for the selection of novel ACE inhibitors (Table 1).

To date, the most commonly used method for the detection of ACE inhibitory activity is evaluated by LineweaverBurk plots [56]. Additionally, there are many methods for evaluating the ACE inhibitory activity in vitro, such as spectrophotometric, fluorometric, radiochemical, highperformance liquid chromatography (HPLC) and capillary electrophoresis (CE) methods $[67,68]$. However, the spectrophotometric assay is complicated and time-consuming; the fluorometric assay is expensive but easy and automated [69]; and the radiochemical assay is unsafe and timeconsuming and require special apparatus [70]. The HPLC assay has a high sensitivity and short operation time, while in comparison to the methods mentioned above, the CE assay is found to be faster and more automated and requires less sample, substrates, and reagents, which suggests that the CE method is more suitable for the high throughput screening of peptides with ACE inhibitory activity [54]. In addition, there is not necessarily an in vivo effect after the identification of an ACE inhibitory peptide in vitro. Thus it is necessary to perform in vivo animal studies using animal models, and the in vivo assay of ACE inhibitory activity is generally conducted by measuring the blood pressure response in spontaneously hypertensive rats following intravenous injection or oral administration [71]. However, the in vivo assays are expensive, time-consuming, and complicated. In conclusion, the establishment of a simple, rapid, sensitive, and reliable inhibition assay is desirable.

2.3. Antimicrobial Peptides. The discovery of the widespread distribution of antimicrobial peptides (AMPs) over the past 20 years has provided insights into the innate defence systems that permit multicellular organisms [72], and AMPs are considered as highly significant immune effectors that have evolved through positive selection [73]. Recently, much 
TABLE 1: Biological activity associated with protein hydrolysates and peptides from marine organisms.

\begin{tabular}{|c|c|c|c|c|c|}
\hline Common name & Scientific name & Origin & Biological activity & Peptide(s) sequence & Reference \\
\hline Hoki & Johnius belengerii & Frame & Antioxidant & $\begin{array}{c}\text { ESTVPERTHPA } \\
\text { CPDFN }\end{array}$ & [9] \\
\hline Mackerel & $\begin{array}{c}\text { Pneumatophorus } \\
\text { japonicus }\end{array}$ & Muscle & Antioxidant & - & {$[10]$} \\
\hline Mussel & Perna canaliculus & Muscle & Antioxidant & $\begin{array}{l}\text { KGYSSYICDK, } \\
\text { SSYCIVKICDK }\end{array}$ & {$[11]$} \\
\hline Croaker & Otolithes ruber & Muscle & Antioxidant & KTFCGRH- & {$[12]$} \\
\hline Tuna & & Backbone & Antioxidant & $\begin{array}{l}\text { VKAGFAWTA } \\
\text { NQQLS }\end{array}$ & [13] \\
\hline Prawn & Penaeus japonicus & Muscle & Antioxidant & IKK, FKK, FIKK & {$[14]$} \\
\hline Sardinelle & Sardinella aurita & Muscle & Antioxidant & $\begin{array}{c}\text { LHT, LAAL, GGG, } \\
\text { GAH, GATA, PHTL, } \\
\text { GALAAH }\end{array}$ & {$[16]$} \\
\hline Jumbo Squid & Dosidicus gigas & Skin & Antioxidant & $\begin{array}{c}\text { FDSGPAGVL, } \\
\text { NGPLQAGQPGER }\end{array}$ & {$[19]$} \\
\hline Sea Cucumber & $\begin{array}{l}\text { Acaudina } \\
\text { molpadioides }\end{array}$ & Whole body & ACE inhibitory & MEGAQEAQGD & {$[31]$} \\
\hline Tuna & - & Frame & Antihypertensive & $\begin{array}{l}\text { GDLGKTTTVS } \\
\text { NWSPPKYKDTP }\end{array}$ & {$[32]$} \\
\hline Sole & Limanda aspera & Frame & Antihypertensive & MIFPGAGGPEL & {$[33]$} \\
\hline Blue Mussel & Mytilus edulis & Whole body & ACE inhibitory & EVMAGNLYPG & {$[34]$} \\
\hline Shrimp & - & Fermented product & ACE inhibitory & SV, IF, WP & [35] \\
\hline Shrimp & $\begin{array}{c}\text { Plesionika izumiae } \\
\text { Omori }\end{array}$ & Whole shrimp & Antihypertensive & VWYHT, VW & {$[36]$} \\
\hline Alaska Pollack & $\begin{array}{c}\text { Theragra } \\
\text { chalcogramma }\end{array}$ & Frame & ACE inhibitory & FGASTRGA & {$[37]$} \\
\hline Alaska Pollack & $\begin{array}{c}\text { Theragra } \\
\text { chalcogramma }\end{array}$ & skin & ACE inhibitory & GPL, GPM & {$[38]$} \\
\hline Tuna & - & Frame & ACE inhibitory & $\begin{array}{l}\text { GDLGKTTTVS } \\
\text { NWSPPKYKDTP }\end{array}$ & {$[32]$} \\
\hline Shark & - & Meat & ACE inhibitory & CF, EY, MF, FE & [39] \\
\hline Oyster & Crassostrea gigas & Muscle & Anti-HIV & LLEYSL, LLEYSI & {$[40]$} \\
\hline Yellow Catfish & $\begin{array}{l}\text { Pelteobagrus } \\
\text { fulvidraco }\end{array}$ & Skin Mucus & Antimicrobial & $\begin{array}{l}\text { GKLNLFLSRLE } \\
\text { ILKLFVGAL }\end{array}$ & {$[41]$} \\
\hline Marine Snail & $\begin{array}{l}\text { Cenchritis } \\
\text { muricatus }\end{array}$ & Whole body & Antifungal & SRSELIVHQR & {$[42]$} \\
\hline Hoki & Johnius belengerii & Frame & Ca-binding & $\begin{array}{c}\text { VLSGGTTMYA } \\
\text { SLYAE }\end{array}$ & {$[43]$} \\
\hline Alaska Pollack & $\begin{array}{l}\text { Theragra } \\
\text { chalcogramma }\end{array}$ & Backbone & Ca-binding & $\begin{array}{c}\text { VLSGGTTMA } \\
\text { MYTLV }\end{array}$ & {$[44]$} \\
\hline Yellowfin Sole & Limanda aspera & Frame & Anticoagulant & $\begin{array}{l}\text { TDGSEDYGILE } \\
\text { IDSR }\end{array}$ & {$[45]$} \\
\hline Spirulina Maxima & - & Whole body & Antiatherosclerotic & LDAVNR, MMLDF & {$[46]$} \\
\hline Blue Mussel & Mytilus edulis & Whole body & Anticoagulant & $\begin{array}{l}\text { EADIDGDGQV } \\
\text { NYEEFVAMMTSK }\end{array}$ & {$[47]$} \\
\hline Oyster & Crassostrea gigas & Muscle & Antitumour & - & {$[48]$} \\
\hline Tuna & Thunnus tonggol & Muscle & Antiproliferative & $\begin{array}{l}\text { LPHVLTPEAGAT, } \\
\text { PTAEGGVYMVT }\end{array}$ & {$[49]$} \\
\hline Pacific Whiting & $\begin{array}{l}\text { Merluccius } \\
\text { productus }\end{array}$ & Whole body & Immunomodulatory & - & {$[50]$} \\
\hline Algae & Pyropia yezoensis & Whole body & Anti-inflammatory & - & {$[51]$} \\
\hline Salmo & Oncorhynchus keta & Skin & Antidiabetic & - & {$[52]$} \\
\hline Brown Shrimp & Penaeus aztecus & Head & Antiobesity & - & {$[53]$} \\
\hline
\end{tabular}


attention has been paid to marine-derived bioactive peptides due to their special living environment, compositions, and properties. The marine organisms are in close contact with microbes and provide a huge source of AMPs. In addition, open ocean seawater harbours have 106 bacterial and 103 fungal cells per millilitre, and most marine organisms host specific populations of microbes on their surfaces or within the confines of their tissues [74]. As stated earlier, this section is to introduce several marine-derived natural products that possess significant antimicrobial properties. In recent years, researchers have isolated AMPs from Atlantic Cod (Gadus morhua) [75], Mud Crab (Scylla paramamosain) [76], Oyster (Crassostrea gigas) [40], Yellow Catfish (Pelteobagrus fulvidraco) [41], Sponge (Trichoderma sp.) [77], and Marine Snail (Cenchritis muricatus) [42], and the AMPs from marine organisms have safe, natural, inexpensive, and high bioactivity properties (Table 1). In addition, several methods for testing the antimicrobial activity of hydrolysates or peptides have been used. For example, the agar diffusion assay is a common method used to test the antimicrobial activity of peptides [78, 79]. This method quantifies the ability of antibiotics to inhibit bacterial growth [80]. The agar diffusion technique is usually used for determining the minimum inhibitory concentration in solid media [81]. Furthermore, there are some other assays to evaluate the antimicrobial activity like the disc diffusion assay [82], broth dilution [83], high throughput fluorescence screening assay [84], and so forth. The growing problem of resistance to conventional antibiotics and the need for new antibiotics has stimulated interest in the development of antimicrobial peptides as human therapeutics [72].

2.4. Other Bioactive Peptides. The peptides from marine organisms also exhibit other bioactivities, such as calcium binding, anticoagulant, antitumour, cardiovascular protective, immunomodulatory, neuroprotective, antidiabetic, and appetite suppression activities $[85,86]$.

There are many researches about the above biological activities; for example, Jung and Kim [43] prepared a peptide from Hoki (Johnius belengerii) bone showing significant Cabinding activity, and the bone could be used in nutraceuticals with a high bioavailability of calcium. Jung et al. [44] also found a low molecular weight peptide with a high affinity to calcium from Alaska Pollack (Theragra chalcogramma) backbone, which makes it possible to utilize the fish backbone in the nutraceutical field. Furthermore, with cardiovascular disease being identified as the leading cause of death worldwide, some researchers have separated cardiovascular protective peptides from Yellowfin Sole (Limanda aspera) [45], Spirulina Maxima [46], Blue Mussel (Mytilus edulis) [47], and other marine organisms (Table 1).

In recent years, there is also a trend to focus on marine organism protein hydrolysates that are used as antitumour agents [87]. For example, Wang et al. [48] have studied the antitumour activity of the Oyster (Crassostrea gigas) hydrolysates in $\mathrm{BALB} / \mathrm{c}$ mice and found the spleen proliferation of lymphocytes and the phagocytic rate of macrophages in S180-bearing mice significantly increased after the administration of the oyster hydrolysates.
Hsu et al. [49] have investigated the antiproliferative activities of peptides from Tuna Dark (Thunnus tonggol) muscle byproduct, and the results showed that the peptide fraction with the molecular weight range from 390 to $1400 \mathrm{Da}$ possessed the greatest antiproliferative activity. Alemán et al. [88] have proven that giant squid gelatine hydrolysates demonstrated an in vitro cytotoxic effect on cancer cells, with IC50 values of 0.13 and $0.10 \mathrm{mg} / \mathrm{mL}$ for MCF-7 (human breast carcinoma) and U87 (glioma) cell lines, respectively. In addition, the effect of immunomodulatory peptides may be due to enhanced macrophage activity and lymphocyte proliferation. Some researchers have found that the phagocytic activity of peritoneal macrophages is enhanced following the administration of fish protein concentrate from Pacific Whiting (Merluccius productus) at $0.3 \mathrm{mg} / \mathrm{ml}$ for 7 days [50]. Yang et al. [89] studied the immunomodulatory effects of marine oligopeptide from Chum Salmon hydrolysate, and, in comparison with the control group, the salmon hydrolysate could significantly enhance the capacity for lymphocyte proliferation. Furthermore, as part of our innate immune system, inflammation is one of the most generic responses, but uncontrolled inflammation is believed to play crucial roles in the pathogenesis of various diseases [90], and there has been a remarkable increase in pharmacological research on anti-inflammatory marine biomolecules in recent years. Novel bioactive peptides from sponges [91], Algae (Pyropia yezoensis) [51], Brown Seaweed [92], and Abalone [93] are also described along with their pharmacological effects in relation to anti-inflammation.

Furthermore, some other bioactive peptides from marine organisms have been investigated. Lee et al. [94] have investigated the antidiabetic effect and mechanism of a Marine Algae (I. foliacea) product in C57BL/KsJ-db/db mice and found that the levels of postprandial blood glucose were significantly lower than the control group. Zhu et al. [52] have also found that the oligopeptides from Marine Salmo (Oncorhynchus keta) skin could significantly reduce the fasting blood glucose in diabetic rats, and they concluded that the antidiabetic activity may be mediated by downregulating T2DM-related oxidative stress and inflammation. Moreover, as obesity has become a serious public health problem throughout the entire world, some marine peptides were found to have antiobesity activity, such as Seaweeds [95], Cod [96], Blue Whiting (Micromesistius poutassou), Brown Shrimp (Penaeus aztecus) [53], and other marine organisms [97]. Although marine organisms comprise roughly one-half of the total global biodiversity and a number of studies exist for proving the biological effects using in vitro experiments or animal models, it is now important to use human intervention trials to study the biological effects and their mechanisms in more detail $[86,98]$.

\section{Preparation of Marine Bioactive Peptides}

The bioactive peptides were different depending on their species, amino acid composition, and sequence, and they can prepared by different methods. Moreover, certain methods also affect the biological activities of peptides [99]. 
3.1. Organic Synthesis. With the development of technologies and methodologies for structural elucidation, organic synthesis is increasingly applied to marine natural products [100]. Due to their special bioactivities, marine natural products have yielded a considerable number of drug candidates, ranging from simple peptides to cyclic peptides, and organic synthesis is always used to batch synthetic target peptides due to the purification production being low [101]. Organic synthesis usually chooses a solid-phase synthesis method using a series of solvents and synthesis methods to obtain the target peptides, and the coarse product is identified by mass spectrometry to test whether it is consistent with the theoretical molecular weight. Its further biological activity would also be verified. Organic synthesis would realize high-volume production of the target peptides. However, the organic synthesis technique is time-consuming, expensive, and environmentally unfriendly. This technique also requires target peptides with a clear sequence. Then the researchers should identify the compositions of peptides using a series of isolation and purification technologies, and, thus, better extraction techniques are preferred.

3.2. Microwave Assisted Extraction. In the last decade, microwave assisted extraction has been successfully applied for the extraction of numerous biologically active compounds from a wide variety of natural resources $[102,103]$. This technique involves the use of electromagnetic radiation in a frequency ranging from $300 \mathrm{MHz}$ to $300 \mathrm{GHz}$ to heat solvents in contact with a sample to separate compounds of interest from the sample matrix [104]. This technique has been reported to enhance the extraction yield of bioactive compounds from various matrices compared to traditional solid-liquid extraction [105]. The mechanism of microwave assisted extraction is through inter- and intramolecular friction, together with the movement and collision of a very large number of charge ions, causing the rapid heating of the reaction system and resulting in the breakdown of cell walls as well as membranes [106]. Although the use of microwave assisted extraction may degrade bioactive carbohydrates due to the localized high temperature [107], there are many reports about extracting bioactive materials from marine organisms using microwave assisted extraction. For example, some researchers have applied a microwave assisted extraction method for fish tissues [108], Oysters [109], and Shrimp [110], and microwave assisted acid hydrolysis of proteins for peptide mass mapping and tandem mass spectrometric analysis of peptides has been reported [111].

Additionally, the microwave assisted technology is suitable for degrading the special organisms, such as Algae, that have cells that are surrounded by a dynamic, complex, and carbohydrate-rich cell wall, which makes the breakdown of cell walls particularly important [112]. For example, some researchers have studied the antioxidant capacity of sulphated polysaccharides from Brown Seaweed [113, 114] using microwave assisted extraction under different pressures, extraction times, and algae/water ratios, and these studies indicated that microwave assisted extraction was an effective technology. Moreover, mechanical disruption techniques are also very useful to break down calcareous and siliceous skeletons of some hard sponges [106].

In general, the compounds are extracted more selectively and quicker by this technique, with similar or better yields in comparison with conventional extraction processes. Meanwhile, this technique also uses less energy and solvent volume, has reduced costs, and is more environmentally friendly than traditional extraction processes [115].

3.3. Chemical Hydrolysis. Chemical hydrolysis of proteins is achieved by cleaving peptide bonds with either acid or alkaline. This method has been widely used in the past for the industry because it is inexpensive and quiet simple to conduct. However, this technology has many limiting factors such as it being a difficult process to control and trend to give modified amino acids [98] and yielding products with variable chemical compositions and functional properties. Acid hydrolysis is an important chemical modification that can significantly change the structure and functional properties of peptides [116]. Acid hydrolysis is preferred over other pretreatments because of its low cost and effectiveness [117]. The most common type of dilute acid used is sulfuric acid $\left(\mathrm{H}_{2} \mathrm{SO}_{4}\right)$. However, nitric acid $\left(\mathrm{HNO}_{3}\right)$, hydrochloric acid $(\mathrm{HCl})$, phosphoric acid $\left(\mathrm{H}_{3} \mathrm{PO}_{4}\right)$, and other acids have also been investigated [118]. Interestingly, maleic acid and oxalic acid were more efficient in biomass hydrolysis than a dose of $\mathrm{H}_{2} \mathrm{SO}_{4}$ [116]. The acid hydrolysis of fish scales has usually involved $\mathrm{HCl}$ [119], and other fish, such as scup, salmon, bluefish, and Mackerel, were hydrolysed by $25 \%$ of $0.4 \mathrm{M} \mathrm{HCl}$ [120]. However, acid hydrolysis usually requires high temperature, and the hydrolysate contains a large amount of salt. Furthermore, acid hydrolysis could destruct the tryptophan, which is an essential amino acid [121]. On the other hand, there are some researches about alkali hydrolysis on samples like Cod [122], Tilapia [123], Channel Catfish [124], and so forth, but alkali hydrolysis often results in poor functionality and low nutritive value [121]. Furthermore, desalination in the later experiment is also complex. Additionally, high collagen solubility is also observed with alkali treatment [125-127]. In other words, chemical hydrolysis can easily cause peptide bond hydrolysis and obtain a high yield of peptides, but this technology is insecure and environmental unfriendly, thus making it mainly used for industrial production.

3.4. Enzyme Hydrolysis. Enzymatic modification of proteins using selected proteolytic enzyme preparations to cleave specific peptide bonds is widely used in the food industry [128]. Enzymatic proteolysis from animal and plant sources has been studied extensively and described by several different authors over the last 60 years [121], and it is still the most commonly used method for adding value to the target organism. The preferred commercial enzymes are prepared from bacterial origin, including Alcalase [13, 129], Neutrase [130, $131]$, and Flavourzyme $[132,133]$, as well as from animals and plants, including trypsin $[68,134]$, Pepsin $[135,136]$, Papain $[137,138]$, Bromelain [139, 140], and Subtilisin [141, 142]. Furthermore, the addition of exogenous enzymes could make the hydrolytic process more controllable and reproducible. There are five independent variables of enzyme hydrolysis 
including the following: enzyme concentration, $\mathrm{pH}$, extraction temperature, extraction time, and water/material ratio, with each enzyme having different hydrolysis conditions [143]. For example, Bhaskar et al. [144] used Alcalase with the optimum conditions of an enzyme to substrate level of $1.5 \%$, and a hydrolysis time of $135 \mathrm{~min}$ to hydrolyse visceral waste proteins of Catla (Catla catla) and obtain a higher degree of hydrolysis close to $50 \%$. Another researcher used Protamex with the optimum conditions of an enzyme to substrate level of $4 \%$, a pH of 7.1 and a temperature of $51^{\circ} \mathrm{C}$ to hydrolyse Blue Shake skin in order to obtain peptide with the highest degree of hydrolysis [145]. In addition, Song et al. [146] studied the hydrolysis conditions of Pepsin with an enzyme to substrate level of $1100 \mathrm{U} / \mathrm{g}$, a $\mathrm{pH}$ of 2.0 , a reaction time of $2.4 \mathrm{~h}$, and a water-to-substrate ratio of $4: 1(\mathrm{v} / \mathrm{w})$. In a word, there are many researchers who have focused on the enzyme hydrolysis due to its reproducibility and controllability [147]; besides, enzymatic reactions do not involve side reactions and do not reduce the nutritional value of the protein source. However, adjusting the $\mathrm{pH}$ with acid or alkali may add inorganic mass, such as salt, which may be difficult and costly to remove later in the process.

\section{Purification of Marine Bioactive Peptides}

The peptides usually have 3-20 amino acid residues, and their bioactivities are based on their amino acid compositions and sequences. Recent studies have shown that most peptide sequences encrypted in food proteins confer bioactive properties after release by enzymatic hydrolysis [148]. Then it is important to identify the peptide structure and that is why so many researchers have investigated the peptide purification.

In a typical procedure for discovery of marine bioactive peptides, the peptides firstly extracted from the marine organisms, the extract is screened for a special bioactivity, fractionated using a bioassay-guided fractionation technology, and finally purified to yield a single bioactive peptide. In addition, to develop an efficient purification process, it is necessary to clearly research methods such as membrane filtration systems, gel or size exclusion chromatography, ionexchange column chromatography, and reversed-phase highperformance liquid chromatography (RP-HPLC) (Figure 1). Each purification technology has its own advantages and disadvantages, which the researcher should consider clearly before the purification of peptides.

4.1. Membrane Filtration. Advances in material science and membrane manufacturing technology have made the membrane technique grow to be an important technology for the separation of natural products [149]. Generally speaking, to obtain the target peptide, the initial peptide is usually separated by membrane filtration first. Membrane filtration can be used at different levels. Ultrafiltration with a high molecular weight cut-off (MWCO) can be used for the separation of macropeptides and nonhydrolyzed proteins. In normal conditions, the peptides have 3-20 amino acid residues, and membranes with an $\mathrm{MWCO}$ at $1-10 \mathrm{kDa}$ are suitable for the fractionation of bioactive peptides with desired molecular weights. Membranes with a low MWCO at approximately $<1 \mathrm{kDa}$ are used to concentrate the peptides. Furthermore, membrane filtration can operate at normal temperature, and there are no chemical reactions during the process (Figure 2). Membrane filtration can provide a large number of separation compared to other chromatographic separation, and then this technology always shows applications for the separation and recovery of bioactive compounds from diverse raw matrices. However, membrane filtration is restricted to desalination due to the poor selectivity of the membrane, while most of chromatographic separation could desalinize, and some researchers have used a nanofiltration membrane for desalination [150]. Certainly, active carbon is also used for desalination [151].

In recent years, many researchers have used membrane filtration as the first purification step. For example, Cho et al. [152] used cross-flow microfiltration to make the galacturonic acid content of pectin increase from 68.0 to $72.2 \%$. Kim et al. [9] used ultrafiltration membranes to separate the Hoki (Johnius belengerii) frame protein hydrolysates $(\mathrm{HPH})$ and found that HPH-III with a molecular weight distribution of $3-5 \mathrm{kDa}$ showed the highest antioxidant activity. Moreover, with ultrafiltration, Wang et al. [10] concentrated and prepurified antioxidative peptides extracted from Mackerel, and they found that the peptide with molecular weight of below $3 \mathrm{kDa}$ displayed the highest 1,1-diphenyl-2-picrylhydrazyl radical scavenging activity. Tonon et al. [153] have obtained a protein hydrolysate from Shrimp by coupling ultrafiltration, and Roblet et al. [154] have used electrodialysis with filtration membranes to purify Atlantic salmon frame protein hydrolysate.

In summary, membrane filtration technology has demonstrated potential application in the separation of bioactive products. The main problem with membrane separation is fouling, which could shorten the membrane life and increase cost. As a result, modification of the structure and properties of the membrane and the development of new membrane systems with low fouling characteristics and high selectivity would promote the development of membrane filtration technology.

4.2. Gel Filtration Chromatography. The partially purified extract is subjected to gel filtration chromatography and ionexchange chromatography, with reversed phase $\mathrm{C}_{18}$ HPLC used in the final purification step $[155,156]$.

Gel filtration chromatography (GFC), also called size exclusion chromatography, has been employed for over 40 years for the separation, desalting, and molecular weight estimation of peptides and proteins. GFC is the simplest and mildest of all of the chromatography techniques and separates molecules on the basis of differences in size. Its separation mechanism is to filter molecules according to their sizes; some smaller molecules enter the pores of the gel and travel a longer distance, while larger molecules show much shorter retention times. Unlike ion-exchange chromatography and others, molecules do not bind to the chromatography medium so the buffer composition does not directly affect the resolution. Consequently, a significant advantage of GFC 


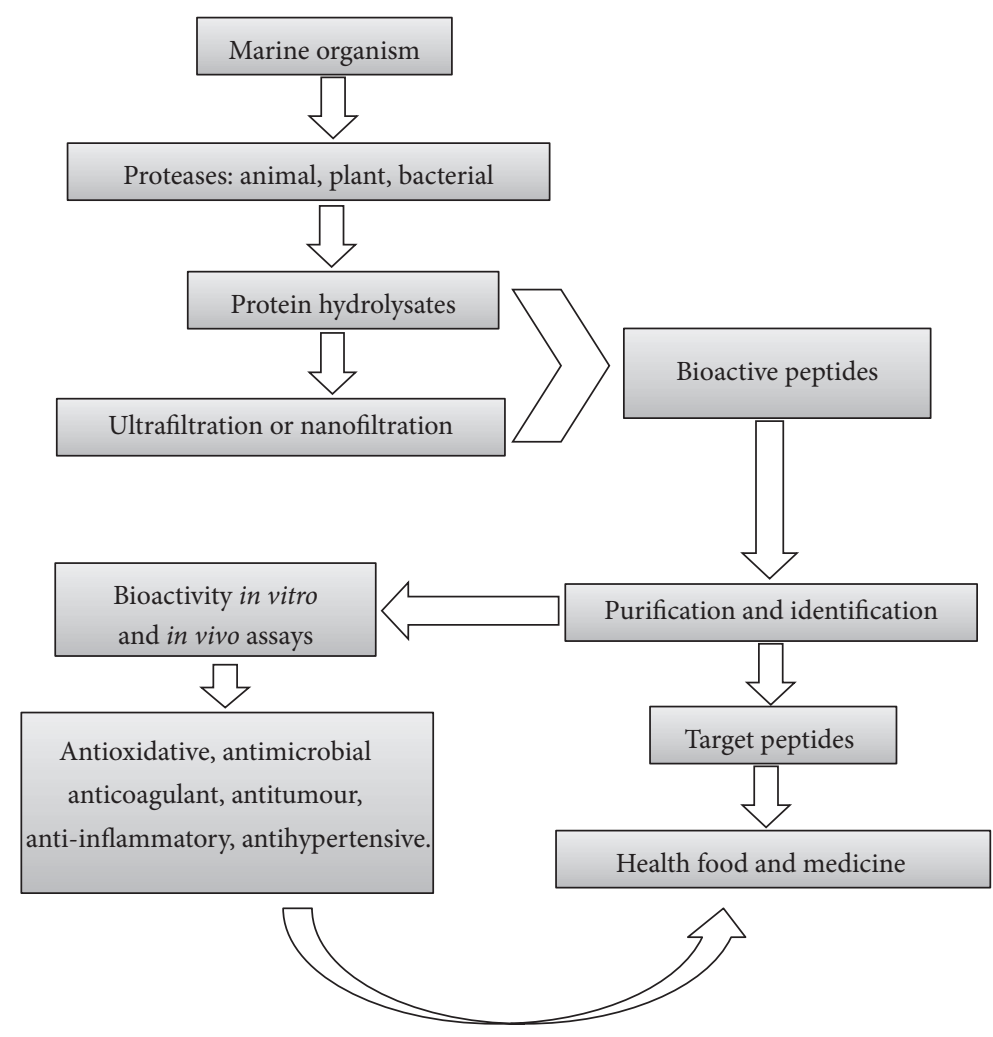

FIGURE 1: Schematic diagram for preparation and purification of biological peptides.

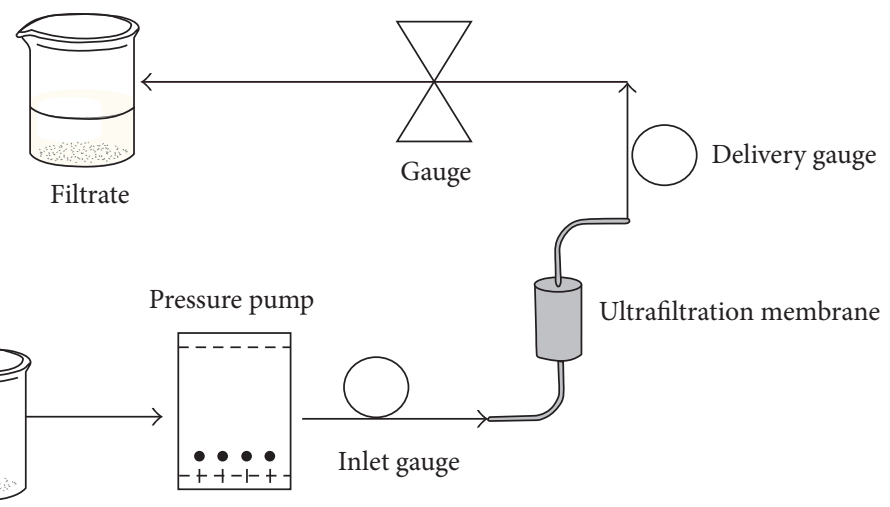

Enzymatic hydrolysate

Figure 2: The flow chart of ultrafiltration method.

is that elution conditions can be varied to suit the type of sample as well as the requirements for further purification, analysis, or storage without altering the separation. GFC is well-suited to biomolecules that are sensitive to changes in $\mathrm{pH}$, concentrations of metal ions, or cofactors as well as harsh environmental conditions and can be used directly after ionexchange chromatography since the buffer composition will not generally affect the final separation. In addition, GFC has high selectivity and high resolution, which is an important step in a purification scheme.

The GFC also has some limitations, such as the loading amount being seldom compared to the membrane filtration and collecting sample costing a lot of time. In addition, the resolution is influenced by many factors, like the particle size, particle uniformity, bed height, column packing quality, flow rate, sample concentration and volume, and so forth. The molecular weight range over which a GFC medium can separate molecules is referred to as the selectivity of the medium. Today's GFC media cover a molecular weight range from 100 to $8 \times 10^{7} \mathrm{Da}$, separating biomolecules from peptides to very large proteins and protein complexes. There are many GFC media and different media have special properties. For example, Superdex Increase or Superdex is designed for high resolution, short run times, and high recovery. Huang et al. [157] 
found a novel polysaccharide peptide with a molecular weight of $9.17 \times 10^{4} \mathrm{Da}$ that was obtained from Clinacanthus nutans Lindau leaves through purification with Superdex 200 and DEAE Sepharose Fast Flow. Qian et al. [158] also used Superdex 200 to purify a protein with a molecular weight of $4.3 \times 10^{4} \mathrm{Da}$, and Pan et al. [159] purified the fish scaledegrading enzyme with molecular weight of $1.19 \times 10^{5} \mathrm{Da}$. Superdex prep grade $[160,161]$ and Sephacryl $[162,163]$ are suitable for fast, high-recovery separation at laboratory and industrial scales. For example, Wu et al. [164] purified trypsin inhibitor from Yellowfin Tuna (Thunnus Albacores) roe, followed by column chromatography on Sephacry S200, Sephadex G-50, and DEAE-cellulose, and it was finally found to have an apparent molecular weight of $7 \times 10^{4} \mathrm{Da}$. In addition, Sephadex is recommended for rapid group separation such as desalting and buffer exchange and it is widely used in the marine organism purification field $[16,165]$. For example, Jai ganesh et al. [156] and Vijaykrishnaraj et al. [11] used Sephadex G-25 to separate Parastromateus Niger viscera and mussel flavour, respectively. In addition, Ma et al. [166] performed the study on the purification of Marine Yeast using Sephadex G-75.

In other words, although GFC is cumbersome, timeconsuming, and costly, its high selectivity and high resolution make this technology applicable to various separation and purification fields.

4.3. Ion-Exchange Chromatography. In recent years, the utilization of ion-exchange chromatography (IEX) techniques for the separation, detection, and structural determination of proteins, peptides, and small nucleotides has become increasingly important [167]. IEX media have charged functional groups that bind molecules with an opposite charge. Bound molecules are eluted from the medium by displacement, via the application of an increasing concentration of a similarly charged molecule. Proteins have numerous functional groups that can have either positive or negative charges. By adjusting the $\mathrm{pH}$ or the ionic concentration of the mobile phase, proteins can be separated. IEX is used for capturing the target protein or bulk impurities from large-volumes, as an intermediate purification step or as a final step for high resolution purification to remove impurities.

Since ion exchange is an adsorption technique, it can be used in either positive or negative capture modes. Depending on the $\mathrm{pH}$ or conductivity of the sample, the target may adsorb while the contaminant is unretained, and this is referred to as positive chromatography. In reverse, it is referred to as negative chromatography. In addition, there is an extensive range of IEX media and a suitable IEX medium can be chosen depending on the target, sample, and resolution that are needed. The media include Capto, MacroCap, MiniBeads, MonoBeads, Sephadex, Sepharose, and SOURCE. Each media has its special working $\mathrm{pH}$, buffer system, and capacity, and, thus, it is used for purifying different type of samples. We can use Sephadex media as an example. DEAE Sephadex is a weak anion exchanger, and its working $\mathrm{pH}$ is 2-9; QAE Sephadex is a strong anion exchanger, and its working $\mathrm{pH}$ is 2-12; and CM Sephadex and
SP-Sephadex are weak cation and strong cation exchangers, respectively, and their working $\mathrm{pH}$ ranges are 6-10 and 4-13, respectively.

Based on above-mentioned properties, many researchers have used different IEX media to purify the target product. For example, Li et al. [151] have used CM Sephadex C-25 to separate chitooligomers with the elution requirement of HAc-NaAc buffer $(50 \mathrm{mM}, \mathrm{pH}=4.8)$ and different concentrations of $\mathrm{NaCl}(0-2 \mathrm{M})-\mathrm{HAc}$ buffer stepwise at $3 \mathrm{~mL} / \mathrm{min}$. Park et al. [168] have purified the antioxidant peptide from Blue Mussel (Mytilus edulis) hydrolysate with SP-Sephadex C-25 cation exchanger, which was equilibrated with $50 \mathrm{mM}$ sodium acetate buffer $(\mathrm{pH}=4.0)$. In addition, SP-Sephadex C-25 is used by other researchers to purify the target peptide $[169,170]$. Additionally, other media such as CM Sepharose Fast Flow [171, 172], DEAE Sepharose Fast Flow [173-175], SP Sepharose Fast Flow [176, 177], Q Sepharose Fast Flow [178], and so forth were applied to purify marine organisms. The great advantage of IEX is the implementation of mass separation compared to GFC, which could save time and improve accuracy. However, IEX is also costly, complex, and is not well-suited to biomolecules that are sensitive to $\mathrm{pH}$, metal ions, and other factors. Further research on IEX may focus on finding a cheap and high resolution material to replace the expensive media. Although this technology is difficult to realize, IEX will be widely applied in biological separation in the future.

4.4. High-Performance Liquid Chromatography. HPLC is the most widely used technique for the separation, identification, and purification of bioactive peptides [179]. Analysis HPLC could fully reflect the information of the sample and do not need to collect fractions; preparative HPLC need to consider the purity, production, production cycle, and operating cost. In addition, RP-HPLC can be used to fractionate peptides based on their hydrophobic properties, especially when studying the structural and functional properties of peptides $[180,181]$. The main advantages of this technology include the ease of operation, high resolution, and sensitivity, and it always uses a short time to get the elution spectra compared to the GFC and IEX, which always need twenty to thirty hours. In recent years, there are many researchers that have used HPLC to purify marine organisms, like Enteromorpha [182], Cyanobacterium [183], Thornback Ray [184], Sponge [185], Tuna [186], Abalone [187], Marine Snail [188], and so forth. The researchers used HPLC with different chromatographic columns and elution conditions to collect the narrow peaks; fractions showing remarkable activities were freeze-dried and further analysed to identify the amino acid composition and sequences, while HPLC also has some limitations, like chromatographic columns being expensive, elution composition containing organic solvent and being environmentally unfriendly, and so forth.

In recent years, HPLC is usually combined with qualitative equipment such as mass spectrometry (MS), and liquid chromatography followed by tandem mass spectrometric detection (LC-MS/MS) is the standard method for the characterization of peptide sequences [98], which has opened a new era in the structural elucidation of protein 
and peptides [189]; although this method is very precise and robust, it remains expensive and time-consuming [190]. In addition, electrospray ionization (ESI) and matrix-assisted laser desorption ionizations (MALDI) have appeared as important tools for protein identification and characterization [191]; matrix-assisted laser desorption/ionization timeof-flight (MALDI-TOF) mass spectrometric analysis is the backbone analysis for generating the peptide profiles of protein hydrolysates or semipurified fractions [179, 192], and so forth.

Besides, in order to alleviate insufficiencies, inadequacy, and disadvantages of the existing techniques, some researchers have developed new, rapid, specific, cost- and time-effective methods, such as high-performance liquid chromatography with evaporative light scattering detection (HPLC-ELSD), which can be used as an investigation tool for purification and quantitative measurements [193]. And as efficiency and speed of analysis have become of great importance in the field of bioanalysis, it is very important to increase the throughput and reduce the analysis costs; ultra-high-performance liquid chromatographytandem mass spectrometry (UHPLC-MS/MS) analysis [194] and rapid resolution liquid chromatography-tandem mass spectrometry (RRLC-MS) [195] give new possibilities in this area.

In summary, there are increasing numbers of high efficiency and high resolution technologies for separation and purification. Thus, researchers should choose appropriate separation methods and media. Although some separation methods are still complex, time-consuming, and costly, scientists are committed to finding better methods to replace them, and the testing method would be more advanced.

\section{Conclusion}

Marine resources have been identified as excellent reservoirs for the extraction of potent functional bioactivities compounds. Therefore, large numbers of bioactive peptides have been isolated from marine organisms and display strong antioxidant, antihypertension, antimicrobial, anticoagulant and antidiabetic activities, and so forth. However, thus far, a limited number of bioactive peptides have been identified from marine organisms; most of the marine organisms with special biological activity are not yet been found. Thus, the existing manufacturing techniques need further improvement in order to find out more marine bioactive peptides. Furthermore, the most important problem is applying the bioactive peptides to human health and nutrition, because most of the researches stay in the stages of in vitro experiment or animal experiment due to the time-consumption and cost problems. In addition, the purification techniques developing rapidly in recent years and various media have been researched and improved; however, low yield and high cost are still a limiting factor. As a result, on the basis of guaranteeing the high selectivity and high resolution, how to improve the separation and purification technology is a difficult and significant task.

\author{
Abbreviations

\begin{tabular}{|c|c|}
\hline ROS: & Reactive oxygen species \\
\hline BHA: & Butylated hydroxyanisole \\
\hline BHT: & Butylated hydroxytoluene \\
\hline CAA: & Cellular antioxidant activity \\
\hline ACE: & Angiotensin-I-converting enzyme \\
\hline HPLC: & High-performance liquid chromatography \\
\hline CE: & Capillary electrophoresis \\
\hline AMPs: & Antimicrobial peptides \\
\hline $\mathrm{H}_{2} \mathrm{SO}_{4}$ : & Sulfuric acid \\
\hline $\mathrm{HNO}_{3}$ : & Nitric acid \\
\hline $\mathrm{HCl}:$ & Hydrochloric acid \\
\hline $\mathrm{H}_{3} \mathrm{PO}_{4}:$ & Phosphoric acid \\
\hline RP-HPLC: & $\begin{array}{l}\text { Reversed-phase high-performance liquid } \\
\text { chromatography }\end{array}$ \\
\hline MWCO: & Molecular weight cut-off \\
\hline GFC: & Gel filtration chromatography \\
\hline IEX: & Ion exchange chromatography \\
\hline MS: & Mass spectrometry \\
\hline ESI: & Electrospray ionization \\
\hline MALDI: & $\begin{array}{l}\text { Matrix-assisted laser desorption } \\
\text { ionizations }\end{array}$ \\
\hline LC-MS/MS: & $\begin{array}{l}\text { Liquid chromatography followed by } \\
\text { tandem mass spectrometric detection }\end{array}$ \\
\hline MALDI-TOF: & $\begin{array}{l}\text { Matrix-assisted laser } \\
\text { desorption/ionization time-of-flight. }\end{array}$ \\
\hline
\end{tabular}

\section{Conflicts of Interest}

The authors declare that there are no conflicts of interest regarding the publication of this paper.

\section{Acknowledgments}

The present study was supported by the National Natural Science Foundation of China (no. 41506175), the Key Research Program of the Chinese Academy of Sciences (no. KFZD-SW-106), Innovation and Development of Marine Economy Demonstration City Project, and the Scientific and Technological Innovation Project Financially Supported by Qingdao National Laboratory for Marine Science and Technology (no. 2015ASKJ02).

\section{References}

[1] D. Destoumieux-Garzón, R. D. Rosa, P. Schmitt et al., "Antimicrobial peptides in marine invertebrate health and disease," Philosophical Transactions of the Royal Society B: Biological Sciences, vol. 371, no. 1695, Article ID 20150300, 2016.

[2] I. Hamed, F. Özogul, Y. Özogul, and J. M. Regenstein, "Marine bioactive compounds and their health benefits: a review," Comprehensive Reviews in Food Science and Food Safety, vol. 14, no. 4, pp. 446-465, 2015.

[3] S. Lordan, R. P. Ross, and C. Stanton, "Marine bioactives as functional food ingredients: potential to reduce the incidence of chronic diseases," Marine Drugs, vol. 9, no. 6, pp. 1056-1100, 2011.

[4] A. Pihlanto-Leppälä, "Bioactive peptides derived from bovine whey proteins: opioid and ace-inhibitory peptides," Trends in Food Science and Technology, vol. 11, no. 9-10, pp. 347-356, 2000. 
[5] J. Ren, M. Zhao, J. Shi et al., "Purification and identification of antioxidant peptides from grass carp muscle hydrolysates by consecutive chromatography and electrospray ionization-mass spectrometry," Food Chemistry, vol. 108, no. 2, pp. 727-736, 2008.

[6] R. Di Bernardini, P. Harnedy, D. Bolton et al., "Antioxidant and antimicrobial peptidic hydrolysates from muscle protein sources and by-products," Food Chemistry, vol. 124, no. 4, pp. 1296-1307, 2011.

[7] P. Kulawik, F. Özogul, R. Glew, and Y. Özogul, "Significance of antioxidants for seafood safety and human health," Journal of Agricultural and Food Chemistry, vol. 61, no. 3, pp. 475-491, 2013.

[8] L. Yu, S. Haley, J. Perret, M. Harris, J. Wilson, and M. Qian, "Free radical scavenging properties of wheat extracts," Journal of Agricultural and Food Chemistry, vol. 50, no. 6, pp. 1619-1624, 2002.

[9] S.-Y. Kim, J.-Y. Je, and S.-K. Kim, "Purification and characterization of antioxidant peptide from hoki (Johnius belengerii) frame protein by gastrointestinal digestion," Journal of Nutritional Biochemistry, vol. 18, no. 1, pp. 31-38, 2007.

[10] X. Wang, R. Xing, S. Liu et al., "Purification and characterization of novel antioxidant peptides of different molecular weights from mackerel Pneumatophorus japonicus protein hydrolysate," Chinese Journal of Oceanology and Limnology, vol. 33, no. 1, pp. 159-168, 2014.

[11] M. Vijaykrishnaraj, B. S. Roopa, and P. Prabhasankar, "Preparation of gluten free bread enriched with green mussel (Perna canaliculus) protein hydrolysates and characterization of peptides responsible for mussel flavour," Food Chemistry, vol. 211, pp. 715-725, 2016.

[12] R. A. Nazeer, N. S. Sampath Kumar, and R. Jai Ganesh, "In vitro and in vivo studies on the antioxidant activity of fish peptide isolated from the croaker (Otolithes ruber) muscle protein hydrolysate," Peptides, vol. 35, no. 2, pp. 261-268, 2012.

[13] J.-Y. Je, Z.-J. Qian, H.-G. Byun, and S.-K. Kim, "Purification and characterization of an antioxidant peptide obtained from tuna backbone protein by enzymatic hydrolysis," Process Biochemistry, vol. 42, no. 5, pp. 840-846, 2007.

[14] K. Suetsuna, "Antioxidant peptides from the protease digest of prawn (Penaeus japonicus) muscle," Marine Biotechnology, vol. 2, no. 1, pp. 5-10, 2000.

[15] S.-K. Kim and E. Mendis, "Bioactive compounds from marine processing byproducts-a review," Food Research International, vol. 39, no. 4, pp. 383-393, 2006.

[16] A. Bougatef, N. Nedjar-Arroume, L. Manni et al., "Purification and identification of novel antioxidant peptides from enzymatic hydrolysates of sardinelle (Sardinella aurita) by-products proteins," Food Chemistry, vol. 118, no. 3, pp. 559-565, 2010.

[17] D. Y. Zhou, B. W. Zhu, L. Qiao et al., "In vitro antioxidant activity of enzymatic hydrolysates prepared from abalone (Haliotis discus hannai Ino) viscera," Food and Bioproducts Processing, vol. 90, no. 2, pp. 148-154, 2012.

[18] S. Choonpicharn, S. Jaturasitha, N. Rakariyatham, N. Suree, and H. Niamsup, "Antioxidant and antihypertensive activity of gelatin hydrolysate from Nile tilapia skin," Journal of Food Science and Technology, vol. 52, no. 5, pp. 3134-3139, 2015.

[19] E. Mendis, N. Rajapakse, H.-G. Byun, and S.-K. Kim, "Investigation of jumbo squid (Dosidicus gigas) skin gelatin peptides for their in vitro antioxidant effects," Life Sciences, vol. 77, no. 17, pp. 2166-2178, 2005.

[20] S. Raghavan, H. G. Kristinsson, and C. Leeuwenburgh, "Radical scavenging and reducing ability of tilapia (Oreochromis niloticus) protein hydrolysates," Journal of Agricultural and Food Chemistry, vol. 56, no. 21, pp. 10359-10367, 2008.

[21] Y. Athukorala, K.-N. Kim, and Y.-J. Jeon, "Antiproliferative and antioxidant properties of an enzymatic hydrolysate from brown alga, Ecklonia cava," Food and Chemical Toxicology, vol. 44, no. 7, pp. 1065-1074, 2006.

[22] S. Bordbar, A. Ebrahimpour, A. Abdul Hamid, M. Y. Abdul Manap, F. Anwar, and N. Saari, "The improvement of the endogenous antioxidant property of stone fish (Actinopyga lecanora) tissue using enzymatic proteolysis," BioMed Research International, vol. 2013, Article ID 849529, 9 pages, 2013.

[23] C.-F. Chi, F.-Y. Hu, B. Wang, Z.-R. Li, and H.-Y. Luo, "Influence of amino acid compositions and peptide profiles on antioxidant capacities of two protein hydrolysates from skipjack tuna (Katsuwonus pelamis) dark muscle," Marine Drugs, vol. 13, no. 5, pp. 2580-2601, 2015.

[24] R. H. Liu and J. Finley, "Potential cell culture models for antioxidant research, vol. 53, no. 10, pp. 4311-4314, 2005.

[25] K. L. Wolfe and H. L. Rui, "Cellular antioxidant activity (CAA) assay for assessing antioxidants, foods, and dietary supplements," Journal of Agricultural and Food Chemistry, vol. 55, no. 22, pp. 8896-8907, 2007.

[26] S. Yarnpakdee, S. Benjakul, H. Kristinsson, and H. Bakken, "Preventive effect of Nile tilapia hydrolysate against oxidative damage of HepG2 cells and DNA mediated by $\mathrm{H}_{2} \mathrm{O}_{2}$ and AAPH," Journal of Food Science and Technology, vol. 52, no. 10, pp. 6194-6205, 2015.

[27] K. W. Kong, S. Mat-Junit, N. Aminudin, F. A. Hassan, A. Ismail, and A. A. Aziz, "Protective effects of the extracts of Barringtonia racemosa shoots against oxidative damage in HepG2 cells," PeerJ, vol. 4, article e1628, 2016.

[28] A. McDowell, S. Thompson, M. Stark, Z.-Q. Ou, and K. S. Gould, "Antioxidant activity of puha (Sonchus oleraceus L.) as assessed by the cellular antioxidant activity (CAA) assay," Phytotherapy Research, vol. 25, no. 12, pp. 1876-1882, 2011.

[29] E. N. Frankel and A. S. Meyer, "The problems of using onedimensional methods to evaluate multifunctional food and biological antioxidants," Journal of the Science of Food and Agriculture, vol. 80, no. 13, pp. 1925-1941, 2000.

[30] F. Granado-Lorencio and E. Hernandez-Alvarez, "Functional foods and health effects: a nutritional biochemistry perspective," Current Medicinal Chemistry, vol. 23, no. 26, pp. 29292957, 2016.

[31] Y. Zhao, B. Li, S. Dong et al., "A novel ACE inhibitory peptide isolated from Acaudina molpadioidea hydrolysate," Peptides, vol. 30, no. 6, pp. 1028-1033, 2009.

[32] S.-H. Lee, Z.-J. Qian, and S.-K. Kim, "A novel angiotensin I converting enzyme inhibitory peptide from tuna frame protein hydrolysate and its antihypertensive effect in spontaneously hypertensive rats," Food Chemistry, vol. 118, no. 1, pp. 96-102, 2010.

[33] W.-K. Jung, E. Mendis, J.-Y. Je et al., “Angiotensin I-converting enzyme inhibitory peptide from yellowfin sole (Limanda aspera) frame protein and its antihypertensive effect in spontaneously hypertensive rats," Food Chemistry, vol. 94, no. 1, pp. 26-32, 2006.

[34] J.-Y. Je, P.-J. Park, H.-G. Byun, W.-K. Jung, and S.-K. Kim, "Angiotensin I converting enzyme (ACE) inhibitory peptide derived from the sauce of fermented blue mussel, Mytilus edulis," Bioresource Technology, vol. 96, no. 14, pp. 1624-1629, 2005.

[35] T. Kleekayai, P. A. Harnedy, M. B. O’Keeffe et al., "Extraction of antioxidant and ACE inhibitory peptides from Thai traditional 
fermented shrimp pastes," Food Chemistry, vol. 176, pp. 441-447, 2015.

[36] Y. Nii, K. Fukuta, R. Yoshimoto, K. Sakai, and T. Ogawa, "Determination of antihypertensive peptides from an izumi shrimp hydrolysate," Bioscience, Biotechnology and Biochemistry, vol. 72, no. 3, pp. 861-864, 2008.

[37] J.-Y. Je, P.-J. Park, J. Y. Kwon, and S.-K. Kim, "A novel angiotensin I converting enzyme inhibitory peptide from Alaska pollack (Theragra chalcogramma) frame protein hydrolysate," Journal of Agricultural and Food Chemistry, vol. 52, no. 26, pp. 7842-7845, 2004.

[38] H.-G. Byun and S.-K. Kim, "Purification and characterization of angiotensin I converting enzyme (ACE) inhibitory peptides from Alaska pollack (Theragra chalcogramma) skin," Process Biochemistry, vol. 36, no. 12, pp. 1155-1162, 2001.

[39] H. Wu, H.-L. He, X.-L. Chen, C.-Y. Sun, Y.-Z. Zhang, and B.C. Zhou, "Purification and identification of novel angiotensinI-converting enzyme inhibitory peptides from shark meat hydrolysate," Process Biochemistry, vol. 43, no. 4, pp. 457-461, 2008.

[40] T.-G. Lee and S. Maruyama, "Isolation of HIV-1 proteaseinhibiting peptides from thermolysin hydrolysate of oyster proteins," Biochemical and Biophysical Research Communications, vol. 253, no. 3, pp. 604-608, 1998.

[41] Y. Su, "Isolation and identification of pelteobagrin, a novel antimicrobial peptide from the skin mucus of yellow catfish (Pelteobagrus fulvidraco)," Comparative Biochemistry and Physiology Part B: Biochemistry and Molecular Biology, vol. 158, no. 2, pp. 149-154, 2011.

[42] C. López-Abarrategui, A. Alba, O. N. Silva et al., "Functional characterization of a synthetic hydrophilic antifungal peptide derived from the marine snail Cenchritis muricatus," Biochimie, vol. 94, no. 4, pp. 968-974, 2012.

[43] W.-K. Jung and S.-K. Kim, "Calcium-binding peptide derived from pepsinolytic hydrolysates of hoki (Johnius belengerii) frame," European Food Research and Technology, vol. 224, no. 6, pp. 763-767, 2007.

[44] W.-K. Jung, R. Karawita, S.-J. Heo, B.-J. Lee, S.-K. Kim, and Y.J. Jeon, "Recovery of a novel Ca-binding peptide from Alaska Pollack (Theragra chalcogramma) backbone by pepsinolytic hydrolysis," Process Biochemistry, vol. 41, no. 9, pp. 2097-2100, 2006.

[45] N. Rajapakse, W.-K. Jung, E. Mendis, S.-H. Moon, and S.-K. Kim, "A novel anticoagulant purified from fish protein hydrolysate inhibits factor XIIa and platelet aggregation," Life Sciences, vol. 76, no. 22, pp. 2607-2619, 2005.

[46] T.-S. Vo and S.-K. Kim, "Down-regulation of histamineinduced endothelial cell activation as potential anti-atherosclerotic activity of peptides from Spirulina maxima," European Journal of Pharmaceutical Sciences, vol. 50, no. 2, pp. 198-207, 2013.

[47] W.-K. Jung and S.-K. Kim, "Isolation and characterisation of an anticoagulant oligopeptide from blue mussel, Mytilus edulis," Food Chemistry, vol. 117, no. 4, pp. 687-692, 2009.

[48] Y.-K. Wang, H.-L. He, G.-F. Wang et al., "Oyster (Crassostrea gigas) hydrolysates produced on a plant scale have antitumor activity and immunostimulating effects in BALB/c mice," Marine Drugs, vol. 8, no. 2, pp. 255-268, 2010.

[49] K.-C. Hsu, E. C. Y. Li-Chan, and C.-L. Jao, "Antiproliferative activity of peptides prepared from enzymatic hydrolysates of tuna dark muscle on human breast cancer cell line MCF-7," Food Chemistry, vol. 126, no. 2, pp. 617-622, 2011.
[50] J. Duarte, G. Vinderola, B. Ritz, G. Perdigón, and C. Matar, "Immunomodulating capacity of commercial fish protein hydrolysate for diet supplementation," Immunobiology, vol. 211, no. 5, pp. 341-350, 2006.

[51] H.-A. Lee, I.-H. Kim, and T.-J. Nam, "Bioactive peptide from Pyropia yezoensis and its anti-inflammatory activities," International Journal of Molecular Medicine, vol. 36, no. 6, pp. 17011706, 2015.

[52] C.-F. Zhu, H.-B. Peng, G.-Q. Liu, F. Zhang, and Y. Li, “Beneficial effects of oligopeptides from marine salmon skin in a rat model of type 2 diabetes," Nutrition, vol. 26, no. 10, pp. 1014-1020, 2010.

[53] B. Cudennec, R. Ravallec-Plé, E. Courois, and M. FouchereauPeron, "Peptides from fish and crustacean by-products hydrolysates stimulate cholecystokinin release in STC-1 cells," Food Chemistry, vol. 111, no. 4, pp. 970-975, 2008.

[54] J. Wilson, M. Hayes, and B. Carney, "Angiotensin-I-converting enzyme and prolyl endopeptidase inhibitory peptides from natural sources with a focus on marine processing by-products," Food Chemistry, vol. 129, no. 2, pp. 235-244, 2011.

[55] C. M. Lawes, S. V. Hoorn, and A. Rodgers, "Global burden of blood-pressure-related disease, 2001," The Lancet, vol. 371, no. 9623, pp. 1513-1518, 2008.

[56] H.-L. He, D. Liu, and C.-B. Ma, "Review on the AngiotensinI-Converting Enzyme (ACE) Inhibitor Peptides from Marine Proteins," Applied Biochemistry and Biotechnology, vol. 169, no. 3, pp. 738-749, 2013.

[57] R. Skrbic and R. Igic, "Seven decades of angiotensin (19392009)," Peptides, vol. 30, no. 10, pp. 1945-1950, 2009.

[58] R. Igic and R. Behnia, "Pharmacological, immunological, and gene targeting of the renin-angiotensin system for treatment of cardiovascular disease," Current Pharmaceutical Design, vol. 13, no. 12, pp. 1199-1214, 2007.

[59] K. Elavarasan, B. A. Shamasundar, F. Badii, and N. Howell, "Angiotensin I-converting enzyme (ACE) inhibitory activity and structural properties of oven- and freeze-dried protein hydrolysate from fresh water fish (Cirrhinus mrigala)," Food Chemistry, vol. 206, pp. 210-216, 2016.

[60] S.-K. Kim and I. Wijesekara, "Development and biological activities of marine-derived bioactive peptides: a review," Journal of Functional Foods, vol. 2, no. 1, pp. 1-9, 2010.

[61] K. R. Acharya, E. D. Sturrock, J. F. Riordan, and M. R. W. Ehlers, "ACE revisited: a new target for structure-based drug design," Nature Reviews Drug Discovery, vol. 2, no. 11, pp. 891-902, 2003.

[62] H. Hu, Y. Deng, Y. Fan et al., "Effects of artificial sweeteners on metal bioconcentration and toxicity on a green algae Scenedesmus obliquus," Chemosphere, vol. 150, pp. 285-293, 2016.

[63] M. Mosquera, B. Giménez, P. Montero, and M. C. GómezGuillén, "Incorporation of liposomes containing squid tunic ACE-inhibitory peptides into fish gelatin," Journal of the Science of Food and Agriculture, vol. 96, no. 3, pp. 769-776, 2016.

[64] G. Riviere, A. Fellous, A. Franco, B. Bernay, and P. Favrel, "A crucial role in fertility for the oyster angiotensin-converting enzyme orthologue CgACE," PLoS ONE, vol. 6, no. 12, Article ID e27833, 2011.

[65] J.-Y. Ko, N. Kang, J.-H. Lee et al., "Angiotensin I-converting enzyme inhibitory peptides from an enzymatic hydrolysate of flounder fish (Paralichthys olivaceus) muscle as a potent antihypertensive agent," Process Biochemistry, vol. 51, no. 4, pp. 535$541,2016$.

[66] A. T. Girgih, I. D. Nwachukwu, F. Hasan, T. N. Fagbemi, T. Gill, and R. E. Aluko, "Kinetics of the inhibition of renin and angiotensin I-converting enzyme by cod (Gadus morhua) 
protein hydrolysates and their antihypertensive effects in spontaneously hypertensive rats," Food and Nutrition Research, vol. 59, Article ID 29788, 2015.

[67] J. Chen, Y. Wang, R. Ye, Y. Wua, and W. Xia, "Comparison of analytical methods to assay inhibitors of angiotensin Iconverting enzyme," Food Chemistry, vol. 141, no. 4, pp. 33293334, 2013.

[68] H. Wu, N. Xu, X. Sun, H. Yu, and C. Zhou, "Hydrolysis and purification of ACE inhibitory peptides from the marine microalga Isochrysis galbana," Journal of Applied Phycology, vol. 27, no. 1, pp. 351-361, 2014.

[69] M. Á. Sentandreu and F. Toldrá, "A rapid, simple and sensitive fluorescence method for the assay of angiotensin-I converting enzyme," Food Chemistry, vol. 97, no. 3, pp. 546-554, 2006.

[70] B. Beneteau-Burnat and B. Baudin, "Angiotensin-converting enzyme: clinical applications and laboratory investigations on serum and other biological fluids," Critical Reviews in Clinical Laboratory Sciences, vol. 28, no. 5-6, pp. 337-356, 1991.

[71] T. Lafarga, E. Gallagher, R. E. Aluko, M. A. E. Auty, and M. Hayes, "Addition of an enzymatic hydrolysate of bovine globulins to bread and determination of hypotensive effects in spontaneously hypertensive rats," Journal of Agricultural and Food Chemistry, vol. 64, no. 8, pp. 1741-1750, 2016.

[72] M. Zasloff, "Antimicrobial peptides of multicellular organisms," Nature, vol. 415, no. 6870, pp. 389-395, 2002.

[73] M. I. El-Gamal, M. S. Abdel-Maksoud, and C.-H. Oh, "Recent advances in the research and development of marine antimicrobial peptides," Current Topics in Medicinal Chemistry, vol. 13, no. 16, pp. 2026-2033, 2013.

[74] C. C. Hughes and W. Fenical, "Antibacterials from the sea," Chemistry - A European Journal, vol. 16, no. 42, pp. 12512-12525, 2010.

[75] D. C. Broekman, A. Zenz, B. K. Gudmundsdottir, K. Lohner, V. H. Maier, and G. H. Gudmundsson, "Functional characterization of codCath, the mature cathelicidin antimicrobial peptide from Atlantic cod (gadus morhua)," Peptides, vol. 32, no. 10, pp. 2044-2051, 2011.

[76] C. Imjongjirak, P. Amparyup, and A. Tassanakajon, “Two novel antimicrobial peptides, arasin-likeSp and GRPSp, from the mud crab Scylla paramamosain, exhibit the activity against some crustacean pathogenic bacteria," Fish and Shellfish Immunology, vol. 30, no. 2, pp. 706-712, 2011.

[77] P. Pruksakorn, M. Arai, N. Kotoku et al., “Trichoderins, novel aminolipopeptides from a marine sponge-derived Trichoderma sp., are active against dormant mycobacteria," Bioorganic and Medicinal Chemistry Letters, vol. 20, no. 12, pp. 3658-3663, 2010.

[78] A. P. Graça, F. Viana, J. Bondoso et al., "The antimicrobial activity of heterotrophic bacteria isolated from the marine sponge Erylus deficiens (Astrophorida, Geodiidae)," Frontiers in Microbiology, vol. 6, 2015.

[79] L. Iturriaga, I. Olabarrieta, and I. M. de Marañón, "Antimicrobial assays of natural extracts and their inhibitory effect against Listeria innocua and fish spoilage bacteria, after incorporation into biopolymer edible films," International Journal of Food Microbiology, vol. 158, no. 1, pp. 58-64, 2012.

[80] L. Najafian and A. S. Babji, "A review of fish-derived antioxidant and antimicrobial peptides: their production, assessment, and applications," Peptides, vol. 33, no. 1, pp. 178-185, 2012.

[81] B. Bonev, J. Hooper, and J. Parisot, "Principles of assessing bacterial susceptibility to antibiotics using the agar diffusion method," Journal of Antimicrobial Chemotherapy, vol. 61, no. 6, pp. 1295-1301, 2008.
[82] S. Mashjoor, M. Yousefzadi, M. A. Esmaeili, and R. Rafiee, "Cytotoxicity and antimicrobial activity of marine macro algae (Dictyotaceae and Ulvaceae) from the Persian Gulf," Cytotechnology, vol. 68, no. 5, pp. 1717-1726, 2016.

[83] S. L. Smith and N. Hinds Vaughan, "Assays optimized for detection and quantification of antibacterial activity in shark cell lysates under high salt conditions," Fish and Shellfish Immunology, vol. 34, no. 5, pp. 1223-1227, 2013.

[84] M. Kodedová and H. Sychrová, "High-throughput fluorescence screening assay for the identification and comparison of antimicrobial peptides' activity on various yeast species," Journal of Biotechnology, vol. 233, pp. 26-33, 2016.

[85] P. A. Harnedy and R. J. FitzGerald, "Bioactive peptides from marine processing waste and shellfish: a review," Journal of Functional Foods, vol. 4, no. 1, pp. 6-24, 2012.

[86] R. C. F. Cheung, T. B. Ng, and J. H. Wong, "Marine peptides: bioactivities and applications," Marine Drugs, vol. 13, no. 7, pp. 4006-4043, 2015.

[87] J. K. Ko and K. K. Auyeung, "Identification of functional peptides from natural and synthetic products on their anticancer activities by tumor targeting," Current Medicinal Chemistry, vol. 21, no. 21, pp. 2346-2356, 2014.

[88] A. Alemán, E. Pérez-Santín, S. Bordenave-Juchereau, I. Arnaudin, M. C. Gómez-Guillén, and P. Montero, "Squid gelatin hydrolysates with antihypertensive, anticancer and antioxidant activity," Food Research International, vol. 44, no. 4, pp. 1044-1051, 2011.

[89] R. Yang, Z. Zhang, X. Pei et al., "Immunomodulatory effects of marine oligopeptide preparation from Chum Salmon (Oncorhynchus keta) in mice," Food Chemistry, vol. 113, no. 2, pp. 464-470, 2009.

[90] R. C. F. Cheung, T. B. Ng, J. H. Wong, Y. Chen, and W. Y. Chan, "Marine natural products with anti-inflammatory activity," Applied Microbiology and Biotechnology, vol. 100, no. 4, pp. 1645-1666, 2016.

[91] J. A. Kim and S. K. Kim, "Bioactive peptides from marine sources as potential anti-inflammatory therapeutics," Current Protein \& Peptide Scoence, vol. 14, no. 3, pp. 177-182, 2013.

[92] K. K. A. Sanjeewa, E.-A. Kim, K.-T. Son, and Y.-J. Jeon, "Bioactive properties and potentials cosmeceutical applications of phlorotannins isolated from brown seaweeds: a review," Journal of Photochemistry and Photobiology B: Biology, vol. 162, pp. 100105, 2016.

[93] Z.-J. Qian, S.-A. Kim, J. S. Lee, H.-J. Kim, I.-W. Choi, and W.-K. Jung, "The antioxidant and anti-inflammatory effects of abalone intestine digest, Haliotis discus hannai in RAW 264.7 macrophages," Biotechnology and Bioprocess Engineering, vol. 17, no. 3, pp. 475-484, 2012.

[94] S.-H. Lee, S.-C. Ko, M.-C. Kang, D. H. Lee, and Y.-J. Jeon, "Octaphlorethol A, a marine algae product, exhibits antidiabetic effects in type 2 diabetic mice by activating AMP-activated protein kinase and upregulating the expression of glucose transporter 4," Food and Chemical Toxicology, vol. 91, pp. 5864, 2016.

[95] M.-C. Kang, N. Kang, S.-C. Ko, Y.-B. Kim, and Y.-J. Jeon, "Antiobesity effects of seaweeds of Jeju Island on the differentiation of 3T3-L1 preadipocytes and obese mice fed a high-fat diet," Food and Chemical Toxicology, vol. 90, pp. 36-44, 2016.

[96] U. Liisberg, K. R. Fauske, O. Kuda et al., "Intake of a Western diet containing cod instead of pork alters fatty acid composition in tissue phospholipids and attenuates obesity and hepatic lipid accumulation in mice," Journal of Nutritional Biochemistry, vol. 33, pp. 119-127, 2016. 
[97] X. Hu, N. Tao, X. Wang, J. Xiao, and M. Wang, "Marine-derived bioactive compounds with anti-obesity effect: a review," Journal of Functional Foods, vol. 21, pp. 372-387, 2016.

[98] M. Vijaykrishnaraj and P. Prabhasankar, "Marine protein hydrolysates: their present and future perspectives in food chemistry-a review," RSC Advances, vol. 5, no. 44, pp. 3486434877, 2015.

[99] D. Agyei, C. M. Ongkudon, C. Y. Wei, A. S. Chan, and M. K. Danquah, "Bioprocess challenges to the isolation and purification of bioactive peptides," Food and Bioproducts Processing, vol. 98, pp. 244-256, 2016.

[100] U. Pindur and T. Lemster, "Advances in marine natural products of the indole and annelated indole series: chemical and biological aspects," Current Medicinal Chemistry, vol. 8, no. 13, pp.16811698, 2001.

[101] Y. Zhou, "The potential biomedical application of cyclopeptides from marine natural products," Current Organic Chemistry, vol. 18, no. 7, pp. 918-924, 2014.

[102] S. Périno-Issartier, Zill-e-Huma, M. Abert-Vian, and F. Chemat, "Solvent free microwave-assisted extraction of antioxidants from sea buckthorn (Hippophae rhamnoides) food by-products," Food and Bioprocess Technology, vol. 4, no. 6, pp. 1020-1028, 2011.

[103] D. A. Navarro, M. L. Flores, and C. A. Stortz, "Microwaveassisted desulfation of sulfated polysaccharides," Carbohydrate Polymers, vol. 69, no. 4, pp. 742-747, 2007.

[104] T. L. Riss, R. A. Moravec, A. L. Niles, H. A. Benink, T. J. Worzella, and L. Minor, "Cell viability assays," in Assay Guidance Manual, 2016.

[105] B. Kaufmann and P. Christen, "Recent extraction techniques for natural products: microwave-assisted extraction and pressurised solvent extraction," Phytochemical Analysis, vol. 13, no. 2, pp. 105-113, 2002.

[106] C. Grosso, P. Valentão, F. Ferreres, and P. B. Andrade, "Alternative and efficient extraction methods for marine-derived compounds," Marine Drugs, vol. 13, no. 5, pp. 3182-3230, 2015.

[107] W. Routray and V. Orsat, "Microwave-assisted extraction of flavonoids: a review," Food and Bioprocess Technology, vol. 5, no. 2, pp. 409-424, 2012.

[108] L. H. Reyes, J. L. G. Mar, G. M. M. Rahman, B. Seybert, T. Fahrenholz, and H. M. S. Kingston, "Simultaneous determination of arsenic and selenium species in fish tissues using microwave-assisted enzymatic extraction and ion chromatography-inductively coupled plasma mass spectrometry," Talanta, vol. 78, no. 3, pp. 983-990, 2009.

[109] M. Bhattacharya, P. P. Srivastav, and H. N. Mishra, "Thin-layer modeling of convective and microwave-convective drying of oyster mushroom (Pleurotus ostreatus)," Journal of Food Science and Technology, vol. 52, no. 4, pp. 2013-2022, 2015.

[110] T. Tsiaka, P. Zoumpoulakis, V. J. Sinanoglou, C. Makris, G. A. Heropoulos, and A. C. Calokerinos, "Response surface methodology toward the optimization of high-energy carotenoid extraction from Aristeus antennatus shrimp," Analytica Chimica Acta, vol. 877, pp. 100-110, 2015.

[111] H. Zhong, S. L. Marcus, and L. Li, "Microwave-assisted acid hydrolysis of proteins combined with liquid chromatography MALDI MS/MS for protein identification," Journal of the American Society for Mass Spectrometry, vol. 16, no. 4, pp. 471-481, 2005.

[112] Z. A. Popper, G. Michel, C. Hervé et al., "Evolution and diversity of plant cell walls: from algae to flowering plants," in Annual Review of Plant Biology, S. S. Merchant, W. R. Briggs, and D. Ort, Eds., vol. 62, pp. 567-588, 2011.
[113] R. M. Rodriguez-Jasso, S. I. Mussatto, L. Pastrana, C. N. Aguilar, and J. A. Teixeira, "Microwave-assisted extraction of sulfated polysaccharides (fucoidan) from brown seaweed," Carbohydrate Polymers, vol. 86, no. 3, pp. 1137-1144, 2011.

[114] Y. Yuan and D. Macquarrie, "Microwave assisted extraction of sulfated polysaccharides (fucoidan) from Ascophyllum nodosum and its antioxidant activity," Carbohydrate Polymers, vol. 129, pp. 101-107, 2015.

[115] J. M. R. Bélanger and J. R. J. Paré, "Applications of microwaveassisted processes (MAP ${ }^{\mathrm{TM}}$ ) to environmental analysis," Analytical and Bioanalytical Chemistry, vol. 386, no. 4, pp. 1049-1058, 2006.

[116] J. Lee and T. W. Jeffries, "Efficiencies of acid catalysts in the hydrolysis of lignocellulosic biomass over a range of combined severity factors," Bioresource Technology, vol. 102, no. 10, pp. 5884-5890, 2011.

[117] Y.-L. Loow, T. Y. Wu, J. M. Jahim, A. W. Mohammad, and W. H. Teoh, "Typical conversion of lignocellulosic biomass into reducing sugars using dilute acid hydrolysis and alkaline pretreatment," Cellulose, vol. 23, no. 3, Article ID A1491, pp. 1491-1520, 2016.

[118] Z. Xu and F. Huang, "Pretreatment methods for bioethanol production," Applied biochemistry and biotechnology, vol. 174, no. 1, pp. 43-62, 2014.

[119] L. Wang, Y. Zou, and B. Jiang, "Process and Kinetic Models of Hydrochloric Acid-Extracted Collagen from Bighead Carp Scale," in Proceedings of the 5th International Conference on Information Engineering for Mechanics and Materials, AERAdvances in Engineering Research, pp. 476-482, Huhhot, Inner Mongolia, July 2015.

[120] N. L. Richard, L. F. Pivarnik, P. C. Ellis, and C. M. Lee, "Impact of quality parameters on the recovery of putrescine and cadaverine in fish using methanol-hydrochloric acid solvent extraction," Journal of AOAC International, vol. 94, no. 4, pp. 1177-1188, 2011.

[121] H. G. Kristinsson and B. A. Rasco, "Fish protein hydrolysates: production, biochemical, and functional properties," Critical Reviews in Food Science and Nutrition, vol. 40, no. 1, pp. 43-81, 2000.

[122] H. G. Kristinsson and H. O. Hultin, "Effect of low and high pH treatment on the functional properties of cod muscle proteins," Journal of Agricultural and Food Chemistry, vol. 51, no. 17, pp. 5103-5110, 2003.

[123] H. G. Kristinsson and B. Ingadottir, "Recovery and properties of muscle proteins extracted from tilapia (Oreochromis niloticus) light muscle by $\mathrm{pH}$ shift processing," Journal of Food Science, vol. 71, no. 3, pp. E132-E141, 2006.

[124] H. G. Kristinsson, A. E. Theodore, N. Demir, and B. Ingadottir, "A comparative study between acid-and alkali-aided processing and surimi processing for the recovery of proteins from channel catfish muscle," Journal of Food Science, vol. 70, no. 4, pp. C298C306, 2005.

[125] C.-Y. Huang, J.-M. Kuo, S.-J. Wu, and H.-T. Tsai, "Isolation and characterization of fish scale collagen from tilapia (Oreochromis sp.) by a novel extrusion-hydro-extraction process," Food Chemistry, vol. 190, pp. 997-1006, 2016.

[126] S. M. Cho, K. S. Kwak, D. C. Park et al., "Processing optimization and functional properties of gelatin from shark (Isurus oxyrinchus) cartilage," Food Hydrocolloids, vol. 18, no. 4, pp. 573579, 2004.

[127] A. Da Trindade Alfaro, C. Simões Da Costa, G. Graciano Fonseca, and C. Prentice, "Effect of extraction parameters on the properties of gelatin from king weakfish (Macrodon 
ancylodon) Bones," Food Science and Technology International, vol. 15, no. 6, pp. 553-562, 2009.

[128] M. M. Mullally, D. M. O’Callaghan, R. J. FitzGerald, W. J. Donnelly, and J. P. Dalton, "Proteolytic and peptidolytic activities in commercial pancreatic protease preparations and their relationship to some whey protein hydrolysate characteristics," Journal of Agricultural and Food Chemistry, vol. 42, no. 12, pp. 29732981, 1994.

[129] A. Sila, N. Sayari, R. Balti et al., "Biochemical and antioxidant properties of peptidic fraction of carotenoproteins generated from shrimp by-products by enzymatic hydrolysis," Food Chemistry, vol. 148, pp. 445-452, 2014.

[130] J.-Y. Je, K.-H. Lee, M. H. Lee, and C.-B. Ahn, "Antioxidant and antihypertensive protein hydrolysates produced from tuna liver by enzymatic hydrolysis," Food Research International, vol. 42, no. 9, pp. 1266-1272, 2009.

[131] M. B. K. Foh, I. Amadou, B. M. Foh, M. T. Kamara, and W. $\mathrm{Xia}$, "Functionality and antioxidant properties of tilapia (Oreochromis niloticus) as influenced by the degree of hydrolysis," International Journal of Molecular Sciences, vol. 11, no. 4, pp. 1851-1869, 2010.

[132] V. Klompong, S. Benjakul, D. Kantachote, and F. Shahidi, "Antioxidative activity and functional properties of protein hydrolysate of yellow stripe trevally (Selaroides leptolepis) as influenced by the degree of hydrolysis and enzyme type," Food Chemistry, vol. 102, no. 4, pp. 1317-1327, 2007.

[133] Y. Liu, W. W. Duan, Z. H. Duan, B. Y. Hu, and I. Destech Publicat, "Study on the Preparation of Oyster Antioxidant Hydrolysates with Different Enzymatic Methods," in Proceedings of the 4th International Conference on Energy and Environmental Protection (Iceep '15), pp. 4225-4233, Iceep, 2015.

[134] A. Alemán, B. Giménez, P. Montero, and M. C. Gómez-Guillén, "Antioxidant activity of several marine skin gelatins," LWT Food Science and Technology, vol. 44, no. 2, pp. 407-413, 2011.

[135] S.-C. Ko, D. Kim, and Y.-J. Jeon, "Protective effect of a novel antioxidative peptide purified from a marine Chlorella ellipsoidea protein against free radical-induced oxidative stress," Food and Chemical Toxicology, vol. 50, no. 7, pp. 2294-2302, 2012.

[136] A. Moreda-Piñeiro, J. Moreda-Piñeiro, P. Herbello-Hermelo et al., "Application of fast ultrasound water-bath assisted enzymatic hydrolysis-high performance liquid chromatographyinductively coupled plasma-mass spectrometry procedures for arsenic speciation in seafood materials," Journal of Chromatography A, vol. 1218, no. 39, pp. 6970-6980, 2011.

[137] L. Tripoteau, G. Bedoux, J. Gagnon, and N. Bourgougnon, "In vitro antiviral activities of enzymatic hydrolysates extracted from byproducts of the Atlantic holothurian Cucumaria frondosa," Process Biochemistry, vol. 50, no. 5, pp. 867-875, 2015.

[138] G.-M. Liu, M.-J. Cao, H.-L. Yu, Y.-H. Hu, L.-J. Zhang, and W.J. Su, "Optimisation of enzymatic hydrolysis of the by-products of marine crab processing using mixed enzymes," International Journal of Food Science and Technology, vol. 45, no. 6, pp. 11981204, 2010.

[139] B. Mbatia, D. Adlercreutz, P. Adlercreutz, A. Mahadhy, F. Mulaa, and B. Mattiasson, "Enzymatic oil extraction and positional analysis of $\omega-3$ fatty acids in Nile perch and salmon heads," Process Biochemistry, vol. 45, no. 5, pp. 815-819, 2010.

[140] J. Salampessy, N. Reddy, K. Kailasapathy, and M. Phillips, "Functional and potential therapeutic ACE-inhibitory peptides derived from bromelain hydrolysis of trevally proteins," Journal of Functional Foods, vol. 14, pp. 716-725, 2015.
[141] P. J. García-Moreno, A. Guadix, E. M. Guadix, and C. Jacobsen, "Physical and oxidative stability of fish oil-in-water emulsions stabilized with fish protein hydrolysates," Food Chemistry, vol. 203, pp. 124-135, 2016.

[142] M. Siwek, B. Galunsky, and B. Niemeyer, "Isolation of selenium organic species from antarctic krill after enzymatic hydrolysis," Analytical and Bioanalytical Chemistry, vol. 381, no. 3, pp. 737741, 2005.

[143] X. Wang, H. Yu, R. Xing, X. Chen, S. Liu, and P. Li, "Optimization of the extraction and stability of antioxidative peptides from mackerel (Pneumatophorus japonicus) protein," BioMed Research International, vol. 2017, Article ID 6837285, 14 pages, 2017.

[144] N. Bhaskar, T. Benila, C. Radha, and R. G. Lalitha, "Optimization of enzymatic hydrolysis of visceral waste proteins of Catla (Catla catla) for preparing protein hydrolysate using a commercial protease," Bioresource Technology, vol. 99, no. 2, pp. 335-343, 2008.

[145] J. C. Rodríguez-Díaz, L. E. Kurozawa, F. M. Netto, and M. D. Hubinger, "Optimization of the enzymatic hydrolysis of Blue shark skin," Journal of Food Science, vol. 76, no. 7, pp. C938C949, 2011.

[146] R. Song, R. Wei, B. Zhang, and D. Wang, "Optimization of the Antibacterial Activity of Half-Fin Anchovy (Setipinna taty) Hydrolysates," Food and Bioprocess Technology, vol. 5, no. 5, pp. 1979-1989, 2012.

[147] S. I. Aspmo, S. J. Horn, and V. G. H. Eijsink, "Enzymatic hydrolysis of Atlantic cod (Gadus morhua L.) viscera," Process Biochemistry, vol. 40, no. 5, pp. 1957-1966, 2005.

[148] D. Agyei and M. K. Danquah, "Industrial-scale manufacturing of pharmaceutical-grade bioactive peptides," Biotechnology Advances, vol. 29, no. 3, pp. 272-277, 2011.

[149] Q. Ren, H. Xing, Z. Bao et al., "Recent advances in separation of bioactive natural products," Chinese Journal of Chemical Engineering, vol. 21, no. 9, pp. 937-952, 2013.

[150] L. Vandanjon, R. Johannsson, M. Derouiniot, P. Bourseau, and P. Jaouen, "Concentration and purification of blue whiting peptide hydrolysates by membrane processes," Journal of Food Engineering, vol. 83, no. 4, pp. 581-589, 2007.

[151] K. Li, R. Xing, S. Liu et al., "Separation of chito-oligomers with several degrees of polymerization and study of their antioxidant activity," Carbohydrate Polymers, vol. 88, no. 3, pp. 896-903, 2012.

[152] C.-W. Cho, D.-Y. Lee, and C.-W. Kim, "Concentration and purification of soluble pectin from mandarin peels using crossflow microfiltration system," Carbohydrate Polymers, vol. 54, no. 1, pp. 21-26, 2003.

[153] R. V. Tonon, B. A. dos Santos, C. C. Couto, C. Mellinger-Silva, A. I. S. Brígida, and L. M. C. Cabral, "Coupling of ultrafiltration and enzymatic hydrolysis aiming at valorizing shrimp wastewater," Food Chemistry, vol. 198, pp. 20-27, 2016.

[154] C. Roblet, M. J. Akhtar, S. Mikhaylin et al., "Enhancement of glucose uptake in muscular cell by peptide fractions separated by electrodialysis with filtration membrane from salmon frame protein hydrolysate," Journal of Functional Foods, vol. 22, pp. 337-346, 2016.

[155] Y. Zhang, X. Duan, and Y. Zhuang, "Purification and characterization of novel antioxidant peptides from enzymatic hydrolysates of tilapia (Oreochromis niloticus) skin gelatin," Peptides, vol. 38, no. 1, pp. 13-21, 2012.

[156] R. Jai ganesh, R. A. Nazeer, and N. S. Sampath Kumar, "Purification and identification of antioxidant peptide from black pomfret, Parastromateus niger (Bloch, 1975) viscera protein 
hydrolysate," Food Science and Biotechnology, vol. 20, no. 4, pp. 1087-1094, 2011.

[157] D. Huang, Y. Li, F. Cui, J. Chen, and J. Sun, "Purification and characterization of a novel polysaccharide-peptide complex from Clinacanthus nutans Lindau leaves," Carbohydrate Polymers, vol. 137, pp. 701-708, 2016.

[158] L. Qian, Y. Zhang, and F. Liu, "Purification and characterization of a $\sim 43 \mathrm{kDa}$ antioxidant protein with antitumor activity from Pholiota nameko," Journal of the Science of Food and Agriculture, vol. 96, no. 3, pp. 1044-1052, 2016.

[159] M.-H. Pan, M.-L. Tsai, W.-M. Chen et al., "Purification and characterization of a fish scale-degrading enzyme from a newly identified Vogesella sp," Journal of Agricultural and Food Chemistry, vol. 58, no. 23, pp. 12541-12546, 2010.

[160] G. Iberer, H. Schwinn, D. Josić, A. Jungbauer, and A. Buchacher, "Improved performance of protein separation by continuous annular chromatography in the size-exclusion mode," Journal of Chromatography A, vol. 921, no. 1, pp. 15-24, 2001.

[161] J. G. Joyce, J. C. Cook, C. T. Przysiecki, and E. Dale Lehman, "Chromatographic separation of low-molecular-mass recombinant proteins and peptides on Superdex 30 prep grade," Journal of Chromatography B: Biomedical Sciences and Applications, vol. 662, no. 2, pp. 325-334, 1994.

[162] M.-J. Cao, K. Osatomi, K. Hara, and T. Ishihara, "Identification of a myofibril-bound serine proteinase (MBSP) in the skeletal muscle of lizard fish Saurida wanieso which specifically cleaves the arginine site," Comparative Biochemistry and Physiology - B Biochemistry and Molecular Biology, vol. 125, no. 2, pp. 255-264, 2000.

[163] J.-D. Shen, Q.-F. Cai, L.-J. Yan et al., "Cathepsin L is an immune-related protein in Pacific abalone (Haliotis discus hannai)-Purification and characterization," Fish and Shellfish Immunology, vol. 47, no. 2, pp. 986-995, 2015.

[164] J.-L. Wu, S.-Y. Ge, Z.-X. Cai et al., "Purification and characterization of a gelatinolytic matrix metalloproteinase from the skeletal muscle of grass carp (Ctenopharyngodon idellus)," Food Chemistry, vol. 145, pp. 632-638, 2014.

[165] K.-C. Hsu, "Purification of antioxidative peptides prepared from enzymatic hydrolysates of tuna dark muscle by-product," Food Chemistry, vol. 122, no. 1, pp. 42-48, 2010.

[166] C. Ma, X. Ni, Z. Chi, L. Ma, and L. Gao, "Purification and characterization of an alkaline protease from the marine yeast Aureobasidium pullulans for bioactive peptide production from different sources," Marine Biotechnology, vol. 9, no. 3, pp. 343-351, 2007.

[167] P. R. Levison, "Large-scale ion-exchange column chromatography of proteins: Comparison of different formats," Journal of Chromatography B: Analytical Technologies in the Biomedical and Life Sciences, vol. 790, no. 1-2, pp. 17-33, 2003.

[168] S. Y. Park, Y.-S. Kim, C.-B. Ahn, and J.-Y. Je, "Partial purification and identification of three antioxidant peptides with hepatoprotective effects from blue mussel (Mytilus edulis) hydrolysate by peptic hydrolysis," Journal of Functional Foods, vol. 20, pp. 8895, 2016.

[169] S. Wang, J. Zhao, L. Chen, Y. Zhou, and J. Wu, "Preparation, isolation and hypothermia protection activity ofantifreeze peptides from shark skin collagen," LWT-Food Science and Technology, vol. 55, no. 1, pp. 210-217, 2014.

[170] S.-Y. Jun, P.-J. Park, W.-K. Jung, and S.-K. Kim, "Purification and characterization of an antioxidative peptide from enzymatic hydrolysate of yellowfin sole (Limanda aspera) frame protein," European Food Research and Technology, vol. 219, no. 1, pp. 2026, 2004.
[171] R. Song, R.-B. Wei, G.-Q. Ruan, and H.-Y. Luo, "Isolation and identification of antioxidative peptides from peptic hydrolysates of half-fin anchovy (Setipinna taty)," LWT-Food Science and Technology, vol. 60, no. 1, pp. 221-229, 2015.

[172] M.-S. Hsieh, L.-J. Yin, and S.-T. Jiang, "Purification and characterization of the amylase from a small abalone Haliotis sieboldii," Fisheries Science, vol. 74, no. 2, pp. 425-432, 2008.

[173] L. Wang, Y. Qu, X. Fu, M. Zhao, S. Wang, and L. Sun, "Isolation, purification and properties of an R-phycocyanin from the phycobilisomes of a marine red macroalga Polysiphonia urceolata," PLoS ONE, vol. 9, no. 2, Article ID e87833, 2014.

[174] N. S. Sampath Kumar, R. A. Nazeer, and R. Jaiganesh, "Purification and biochemical characterization of antioxidant peptide from horse mackerel (Magalaspis cordyla) viscera protein," Peptides, vol. 32, no. 7, pp. 1496-1501, 2011.

[175] L. Ye, L. Xu, and J. Li, "Preparation and anticoagulant activity of a fucosylated polysaccharide sulfate from a sea cucumber Acaudina molpadioidea," Carbohydrate Polymers, vol. 87, no. 3, pp. 2052-2057, 2012.

[176] L. Beaulieu, J. Thibodeau, M. Desbiens, R. Saint-Louis, C. Zatylny-Gaudin, and S. Thibault, "Evidence of antibacterial activities in peptide fractions originating from snow crab (Chionoecetes opilio) by-products," Probiotics and Antimicrobial Proteins, vol. 2, no. 3, pp. 197-209, 2010.

[177] W. S. Huang, K. J. Wang, M. Yang, J. J. Cai, S. J. Li, and G. Z. Wang, "Purification and part characterization of a novel antibacterial protein Scygonadin, isolated from the seminal plasma of mud crab, Scylla serrata (Forskål, 1775)," Journal of Experimental Marine Biology and Ecology, vol. 339, no. 1, pp. 3742, 2006.

[178] H. Chen, S.-H. Shen, G.-C. Wang, L.-B. Li, and T.-Y. Kuang, "Isolation of the main light-harvesting chlorophyll a/b-protein complex from thylakoid membranes of marine alga, Bryopsis corticulans by a direct method," Acta Botanica Sinica, vol. 46, no. 8, pp. 915-920, 2004.

[179] B. P. Singh, S. Vij, and S. Hati, "Functional significance of bioactive peptides derived from soybean," Peptides, vol. 54, pp. 171-179, 2014.

[180] R. Song, K.-Q. Zhang, and R.-B. Wei, "In vitro antioxidative activities of squid (Ommastrephes bartrami) viscera autolysates and identification of active peptides," Process Biochemistry, vol. 51, no. 10, pp. 1674-1682, 2016.

[181] P. B. T. So, P. Rubio, S. Lirio et al., "In vitro angiotensin I converting enzyme inhibition by a peptide isolated from Chiropsalmus quadrigatus Haeckel (box jellyfish) venom hydrolysate," Toxicon, vol. 119, pp. 77-83, 2016.

[182] S. Pan, S. Wang, L. Jing, and D. Yao, "Purification and characterisation of a novel angiotensin-I converting enzyme (ACE)inhibitory peptide derived from the enzymatic hydrolysate of Enteromorpha clathrata protein," Food Chemistry, vol. 211, pp. 423-430, 2016.

[183] J. A. V. Lopez, S. S. Al-Lihaibi, W. M. Alarif et al., "Wewakazole B, a Cytotoxic Cyanobactin from the Cyanobacterium Moorea producens Collected in the Red Sea," Journal of Natural Products, vol. 79, no. 4, pp. 1213-1218, 2016.

[184] I. Lassoued, L. Mora, A. Barkia, M.-C. Aristoy, M. Nasri, and F. Toldrá, "Bioactive peptides identified in thornback ray skin's gelatin hydrolysates by proteases from Bacillus subtilis and Bacillus amyloliquefaciens," Journal of Proteomics, vol. 128, pp. 8-17, 2015.

[185] D. T. A. Youssef, L. A. Shaala, G. A. Mohamed, J. M. Badr, F. H. Bamanie, and S. R. M. Ibrahim, "Theonellamide G, a potent antifungal and cytotoxic bicyclic glycopeptide from the red sea 
marine sponge Theonella swinhoei," Marine Drugs, vol. 12, no. 4, pp. 1911-1923, 2014.

[186] J.-K. Seo, M. J. Lee, H.-G. Jung, H.-J. Go, Y. J. Kim, and N. G. Park, "Antimicrobial function of $\mathrm{SH} \beta \mathrm{AP}$, a novel hemoglobin $\beta$ chain-related antimicrobial peptide, isolated from the liver of skipjack tuna, Katsuwonus pelamis," Fish and Shellfish Immunology, vol. 37, no. 1, pp. 173-183, 2014.

[187] V.-T. Nguyen, Z.-J. Qian, B. Ryu et al., "Matrix metalloproteinases (MMPs) inhibitory effects of an octameric oligopeptide isolated from abalone Haliotis discus hannai," Food Chemistry, vol. 141, no. 1, pp. 503-509, 2013.

[188] P. Dolashka, V. Moshtanska, V. Borisova et al., "Antimicrobial proline-rich peptides from the hemolymph of marine snail Rapana venosa," Peptides, vol. 32, no. 7, pp. 1477-1483, 2011.

[189] M. Careri and A. Mangia, "Analysis of food proteins and peptides by chromatography and mass spectrometry," Journal of Chromatography A, vol. 1000, no. 1-2, pp. 609-635, 2003.

[190] M. Mann and O. N. Jensen, "Proteomic analysis of posttranslational modifications," Nature Biotechnology, vol. 21, no. 3, pp. 255-261, 2003.

[191] J. Léonil, V. Gagnaire, D. Mollé, S. Pezennec, and S. Bouhallab, "Application of chromatography and mass spectrometry to the characterization of food proteins and derived peptides," Journal of Chromatography A, vol. 881, no. 1-2, pp. 1-21, 2000.

[192] H. F. Alomirah, I. Alli, and Y. Konishi, "Applications of mass spectrometry to food proteins and peptides," Journal of Chromatography $A$, vol. 893, no. 1, pp. 1-21, 2000.

[193] M. Tenon, N. Feuillère, M. Roller, and S. Birtić, "Rapid, cost-effective and accurate quantification of Yucca schidigera Roezl. steroidal saponins using HPLC-ELSD method," Food Chemistry, vol. 221, pp. 1245-1252, 2017.

[194] T. M. Rizzetti, M. P. de Souza, O. D. Prestes, M. B. Adaime, and R. Zanella, "A Simple and Fast Method for the Determination of 20 Veterinary Drug Residues in Bovine Kidney and Liver by Ultra-High-Performance Liquid Chromatography Tandem Mass Spectrometry," Food Analytical Methods, vol. 10, no. 4, pp. 854-864, 2017.

[195] J. Li, C. Mao, L. Li et al., "Pharmacokinetics and liver distribution study of unbound curdione and curcumol in rats by microdialysis coupled with rapid resolution liquid chromatography (RRLC) and tandem mass spectrometry," Journal of Pharmaceutical and Biomedical Analysis, vol. 95, pp. 146-150, 2014. 

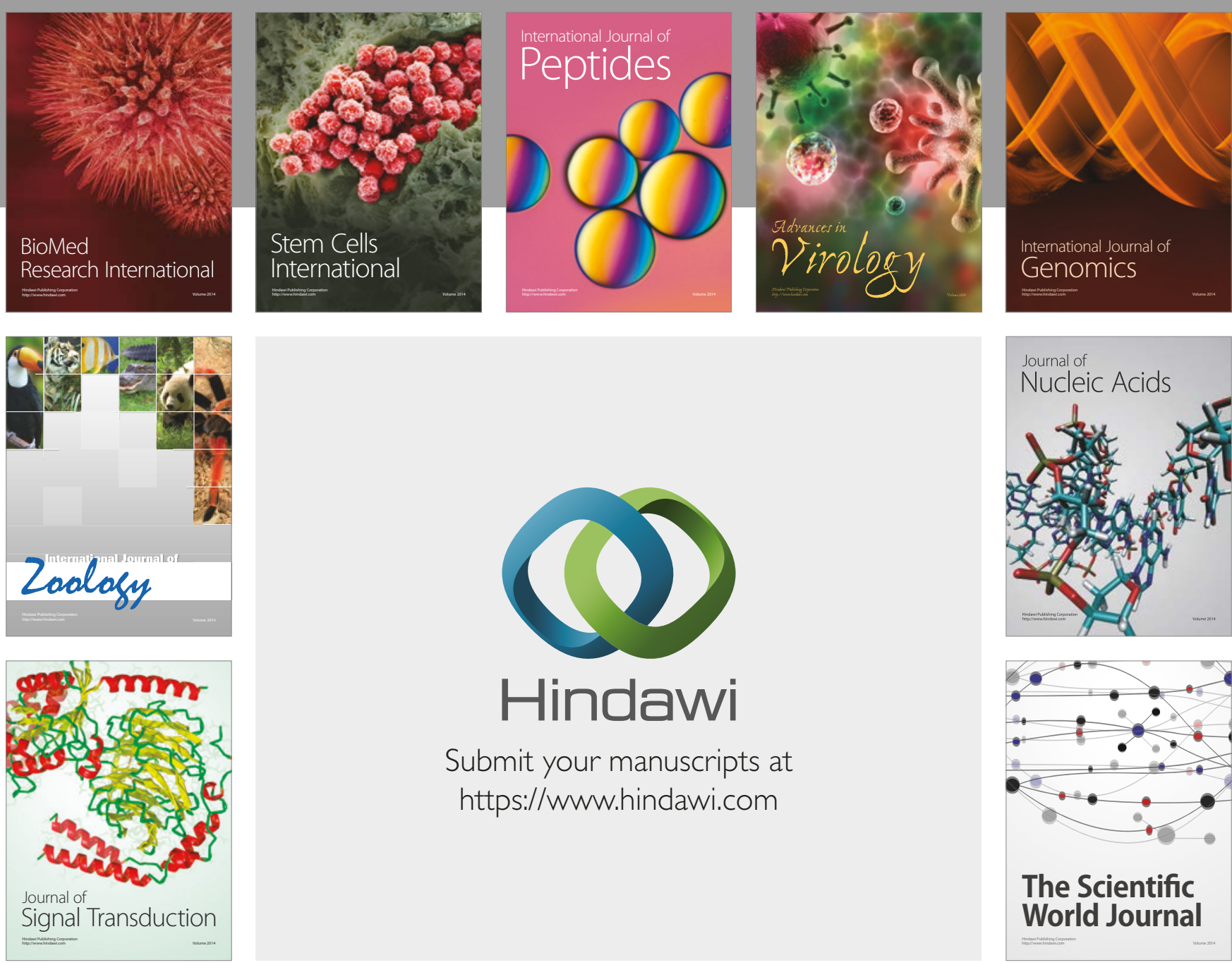

Submit your manuscripts at

https://www.hindawi.com
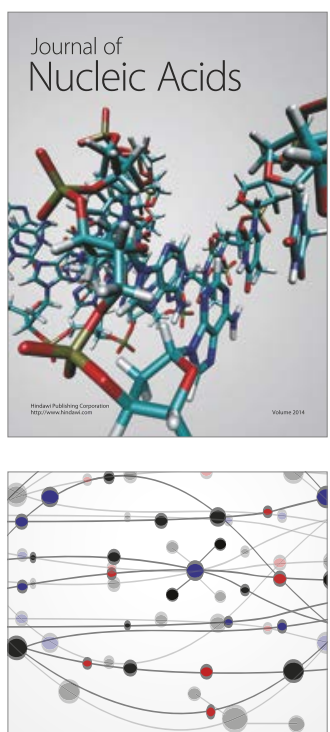

The Scientific World Journal

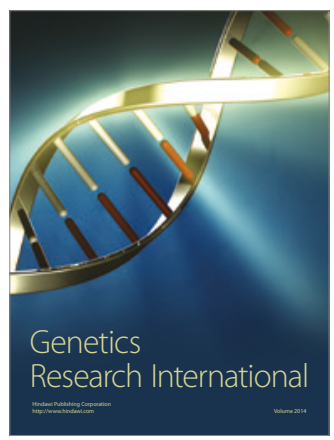

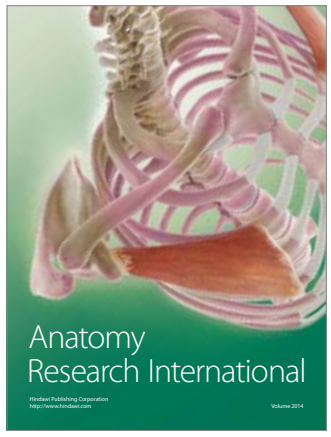

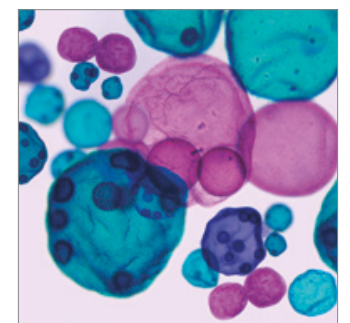

International Journal of Microbiology
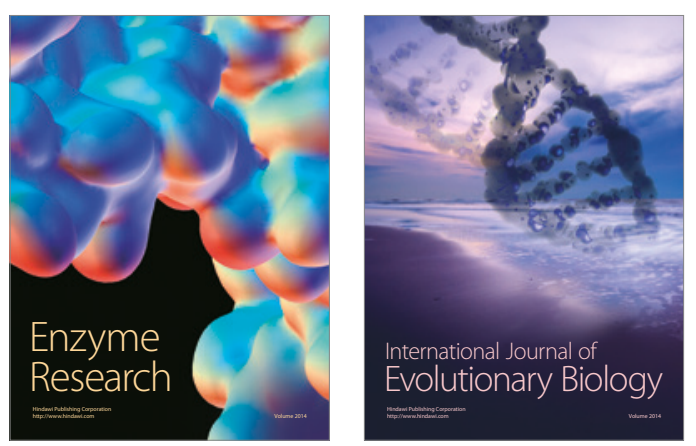
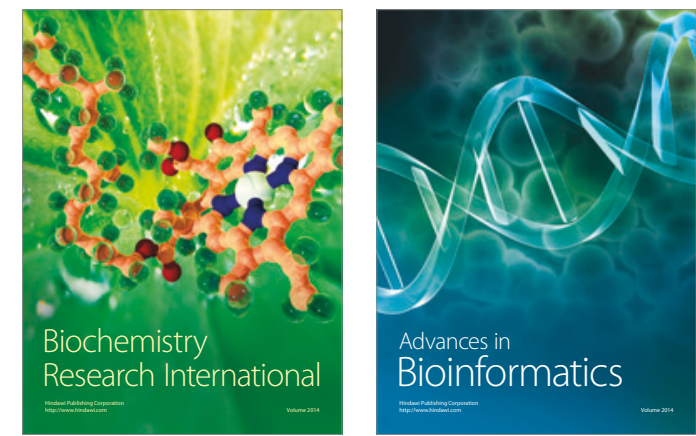

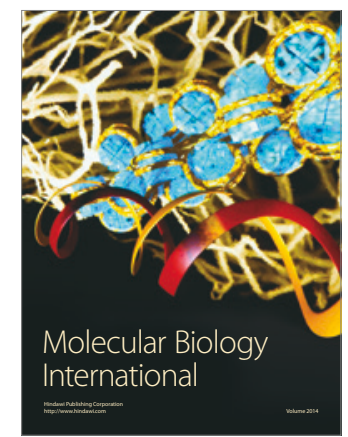

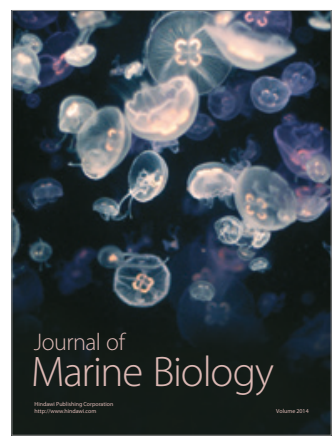

